\title{
The Drivers and Barriers of Renewable Energy Applications and Development in Uganda: A Review
}

\author{
Adebayo Fashina ${ }^{1,2, *(\mathbb{D})}$, Mustafa Mundu ${ }^{2}$, Oluwole Akiyode ${ }^{3}{ }^{(\mathbb{D}}$, Lookman Abdullah ${ }^{4}$, \\ Dahiru Sanni ${ }^{5}$ and Living Ounyesiga ${ }^{2}$ \\ 1 Department of Mathematics and Natural Sciences, Tubman University, P.O. Box 3570, Harper 00231, Liberia \\ 2 Department of Physical Sciences, Kampala International University, P.O. Box 20000, Kampala 00256, Uganda; \\ mundumustafa@yahoo.com (M.M.); ounyesigaliving@gmail.com (L.O.) \\ 3 Department of Biological and Environmental Sciences, Kampala International University, P.O. Box 20000, \\ Kampala 00256, Uganda; woleakiyode@gmail.com \\ 4 Department of Biomedical Physics, King Faisal Specialist Hospital and Research Center, P.O. Box 40047, \\ Jeddah 21449, Saudi Arabia; lookmanabdullah@yahoo.com \\ 5 Department of Theoretical and Applied Physics, African University of Science and Technology, PMB 681, \\ Garki, Abuja 900001, Nigeria; dahirusanni@gmail.com \\ * Correspondence: adebayofashina@gmail.com or afashina@tubmanu.edu.lr; Tel.: +231-88-181-2237
}

Received: 9 March 2018; Accepted: 27 April 2018; Published: 6 May 2018

\begin{abstract}
Following the increasing global awareness of the dangers posed by the present state of climate change, many countries such as Uganda have adapted long-term plans for a transition to decarbonised economies. A major strategy for decarbonisation is to replace fossil fuels with renewable energy (RE) sources as the fundamental energy source. Uganda has substantial RE resources for the provision of energy services and production, yet these resources remain untapped. It is therefore crucial that the use of these abundant resources should be heightened. This paper examines and discusses the potential and current RE utilization and development in Uganda from the perspective of sustainable development. The status of the different RE resources and their application/utilization, including details of existing projects in the country, are carefully explored and discussed. The possible drivers for a huge advancement of RE applications and development in Uganda are also discussed before elucidating the major barriers and challenges faced by the energy sector as regards RE. Measures and policies required to facilitate the utilization of RE in Uganda are proposed. These evidence-based policies could guide the delivery of affordable and sustainable energy solutions for all by 2030 in Uganda.
\end{abstract}

Keywords: renewable energy (RE); solar; hydropower; wind; geothermal; biomass; energy policy; Uganda

\section{Introduction}

Presently, the exigent need for a sustainable approach to global development has been a recurrent subject of discussion at national [1], regional [2,3], and international levels [4], following the United Nations Sustainable Development Summit on the 25th of September 2015, where the world leaders adopted the 2030 Agenda for Sustainable Development [4]. These goals include a set of seventeen sustainable development goals (SDGs) geared towards putting an end to poverty, fighting inequality and injustice, and tackling challenges associated with climate change by 2030 [4]. However, considering Africa's needs in terms of the sustainable development goals for energy (SDG7), it is likely that few African countries could achieve this goal by 2030, if proper governance and policies are put in place to develop short and long term affordable solutions to the energy needs of people living on less than 
\$1-2 a day in rural and urban areas of Africa, where most of the people use environment-polluting kerosene lanterns to provide light at night $[5,6]$.

Energy plays a crucial role in the development and sustainability of a nation's economy $[7,8]$. It has a key impact on all facets of socio-economic activities in many nations of the world today $[9,10]$. This is because energy drives all other sectors of the economy, such as food, health, the environment, water, and so on $[9,10]$. In addition, the future economic growth of a nation is said to be guaranteed when there is a continuous energy supply that is eco-friendly, sustainable, accessible and affordable [7-10]. However, the quality of life (health, education, security etc.) of the citizen of any nation is closely dependent on the adequacy of the available energy supply [9]. In general, the increasing demand for energy in the world today is linearly proportional to the rapid increase in population, industrialization and urbanization [11-13].

Moreover, the success and productivity of the SDG7 depend on the quality and quantity of the available energy in the least developed countries [14-16]. This implies that an increase in the accessibility of affordable and clean energy in most parts of Africa is vital to the political and socio-economic growth of the continent.

Prior work has been carried out on the exploitation of renewable energy (RE) resources in some African countries [17-28]. Some of these works revealed the status of energy in these African countries and proposed the possible measures that can help bolster the use of RE in these countries [20,24-28]. One of these studies was conducted by Mohammed et al. [20], wherein the authors reviewed the exploitation of RE resources in sub-Saharan African, including biomass, geothermal, hydropower, solar, and wind [20]. They further elucidated the need to incorporate power generated from RE to conventional power generation in order to advance the energy access of these countries. In 2011, Hensley et al. [29] presented a review of the potential of biomass energy and bioenergy resources available for rural electrification in Ghana [29]. They concluded that an increased investment in RE resources would in the long run improve the national grid supply, boost energy security and advance sustainable development [29]. Suberu et al. [23] in another study suggested that there is an increase in exploitation of wood-based bioenergy in the same region, particularly in Nigeria, Ghana, and Uganda [23]. The authors revealed that the huge increase in bioenergy consumption in the form of wood fuel has led to deforestation, which in turn affects the environment [23]. These challenges are associated with sustainable development and can be traceable to some technological constraints that are related to local food systems and environmental protection issues as identified by Osei in Ref. [30].

Furthermore, prior work has also been carried out on the status and potential of renewable energy technologies (RETs) in the Eastern Africa region. One of these notable works is recorded in Ref. [31] by Kiplagat et al. The authors suggested that, of all the RE sources in Kenya, biomass energy has an enormous potential to help meet the country's increasing energy demand [31]. They concluded that energy derived from biowaste residues could play a vital role as an alternative to fossil fuel-based generated electricity in Kenya [31]. In addition, using Mpala village in the Laikipia district of Kenya as a model for finding ways of developing sustainable solutions to problems of energy in rural villages, Tong et al. [32] conducted a survey assessment between 2010 and 2012 to determine the factors that affected the adoption of solar lanterns in the community and assess their impact on the villager's socio-economic, health, and education levels [32]. Prior to the two-year questionnaire study that identified the key factors that resulted in the adoption rate of $96 \%$ and a decrease of $14.7 \%$ in annual family expenditures, the authors had developed ways of converting old kerosene lanterns to solar powered lanterns at a cost of about US \$ 25 per lamp [32]. The social, educational, and health impacts were found to be part of the factors that influenced the adoption and diffusion of solar lanterns in this community. The results of their study provided new insights that are now used to formulate business strategies that could improve energy access in rural/urban communities of Africa [32]. Kihwele et al. [26] also presented the visions toward a future Tanzanian power grid. They investigated the planning and regulation of rural electrification and the generation power system in Tanzania, another part of East Africa [26]. The authors further developed scenarios to support the planning 
and integration of diverse components of the smart grid that can be envisioned to be a policy framework for the Government of Tanzania at all levels of action [26].

In another study by Okello et al. [27] on the potential of forest and agricultural residue-based bioenergy, the authors revealed that bioenergy can provide a significant contribution to the diversification of RE in Uganda. The study also recommended the use of improved bioenergy technologies if sustainable biomass energy production is to be guaranteed as well as reducing the harmful environmental impacts $[27,33]$. However, in spite of the efforts made towards improving the biomass sector, there is a need to change the present technology used for biomass consumption [34]. This is a possible solution that can strengthen the bioenergy production in Uganda. Also, in a recent work by Twaha et al. [35], the authors explored the resource potential and status of exploitation of renewable-based distributed generation in Uganda that includes biomass, hydropower, solar, wind, and geothermal energy resources [35]. However, the authors did not identify the present or potential drivers of RE in Uganda as they relate to their proposed policies that could help overcome the identified RE challenges.

The aim of this paper is to provide the current situation and potential of RE utilization and development in Uganda before elucidating the drivers and barriers associated with development of RE applications in the country. The paper also provides a significant analysis of the policy instruments and measures that can effectively contribute to the tremendous growth of RETs in Uganda.

\section{The Status Quo of Renewable Energy Technologies in Uganda}

RE resources are some of the most promising and important assets that can have a multiplier effect on the development of any nation [36-38]. It is an eminent fact that the degree of industrialization is a function of the quantity of energy available and the extent to which that energy is utilized [11]. According to the International Energy Agency (IEA) data (See Figure 1) [39], global energy consumption is estimated to be 168,515 terawatt-hours ( 575 quadrillion Btu) [39] with only 3\% of the world energy consumed in Africa as at 2010 [40], making Africa the region with the smallest per capita consumption of electricity in the world, despite the abundant energy resources available in the region (See Figure 2) [40].

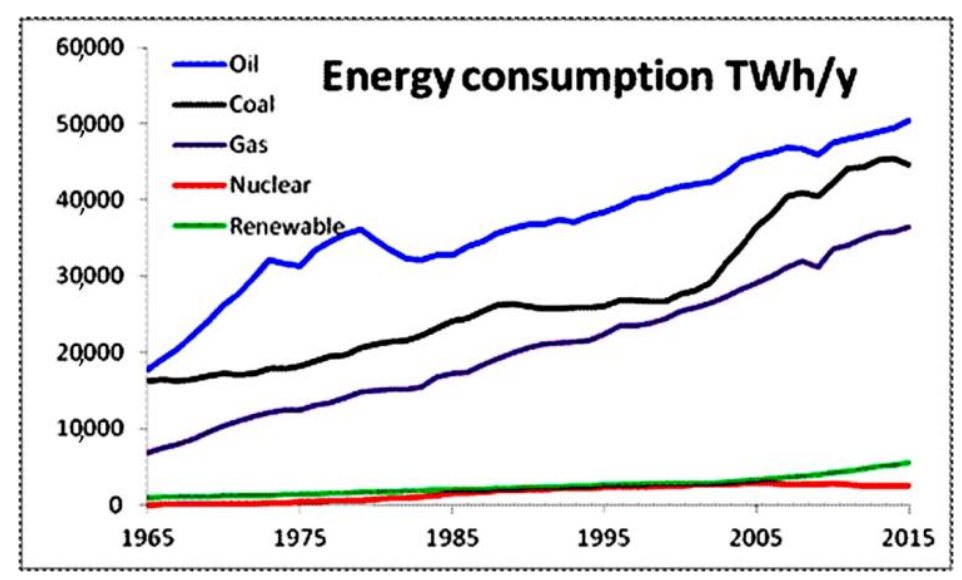

Figure 1. The world's increasing demand for energy [39]. 


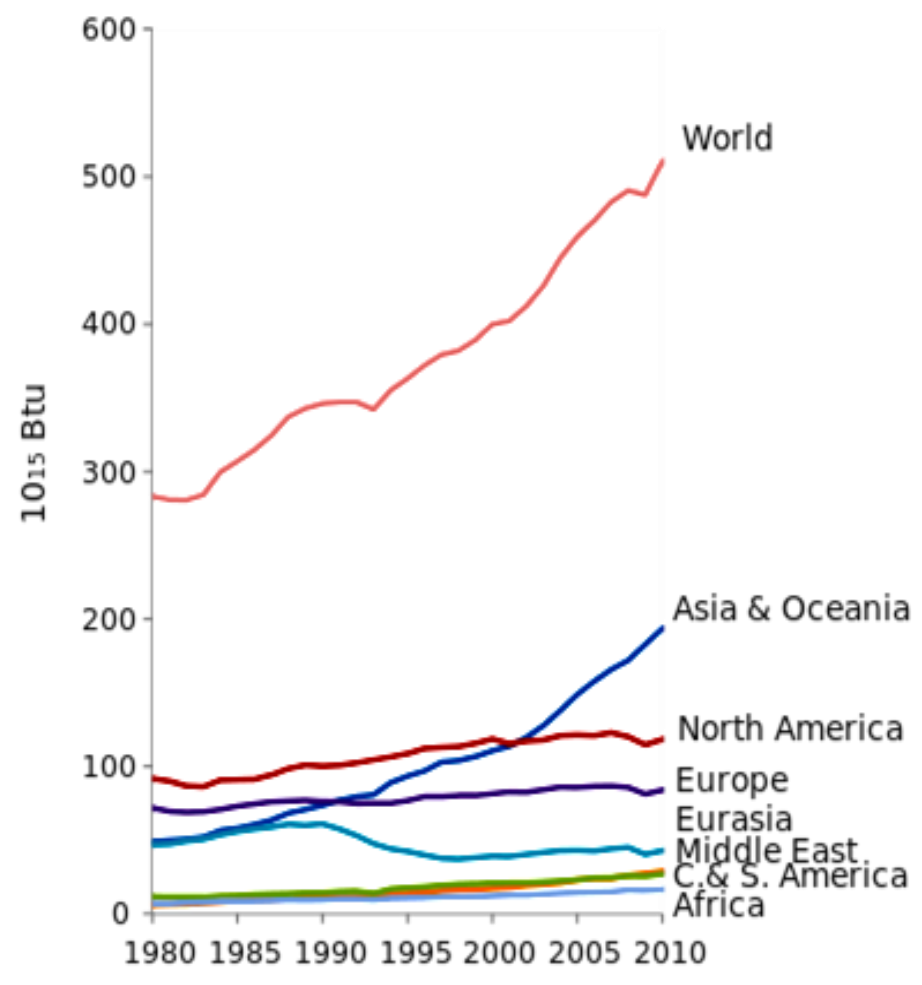

Figure 2. World primary energy consumption in quadrillion [40].

Uganda is a landlocked nation that has substantial RE resources that are distributed evenly across the country [41]. These include wind, hydroelectric, solar, peat, geothermal, biomass-based cogeneration, biomass, and biogas. However, hydropower remains the nation's dominant source for electric energy production with a potential of over $4100 \mathrm{MW}[42,43]$. On the other hand, geothermal possess a potential of $450 \mathrm{MW}$, biomass cogeneration a potential $1650 \mathrm{MW}$, biomass has an annual yield of 50 million tons, solar energy an average of $5.1 \mathrm{KWh} / \mathrm{m}^{2}$, and about $800 \mathrm{MW}$ for peat (250 million tonnes of oil equivalent (Mtoe)) [43]. In general, the overall RE power generation potential is estimated to be about 7200 MW (See Table 1) [42,43]. Some of these RE resources have never been developed while others are not fully developed. With regards to electricity capacity, hydroelectricity accounts for about $84 \%$ of the total installed capacity of $822 \mathrm{MW}$ (See Table 2) [43]. Concerning the total primary energy consumption, biomass is presently the most essential energy source for most of the Ugandan populace, accounting for $90 \%$ of energy consumed (firewood: $78.6 \%$, charcoal: $5.6 \%$, crop residues: $4.7 \%)[43]$.

Table 1. Renewable energy (RE) power potential in Uganda [43].

\begin{tabular}{cc}
\hline Energy Source & Estimated Electrical Potential (MW) \\
\hline Hydro & 4137 \\
Geothermal & 450 \\
Biomass cogeneration & 1650 \\
Solar & 200 \\
Peat & 800 \\
Wind & Yet to be determined \\
Total & 7237 \\
\hline
\end{tabular}

Data Source: Ministry of Energy and Mineral Development, Uganda. 
Table 2. Uganda's most important power stations.

\begin{tabular}{cc}
\hline Plant/Source & Capacity (MW) \\
\hline Kiira (large hydropower station) & 200 \\
Nalubaale (large hydropower station) & 180 \\
Bujagali (large hydropower station) & 250 \\
Jacobsen Namanve (thermal power plant) & 50 \\
Electro-Maxx-Tororo (thermal power plant) & 50 \\
Kakira Sugar Works Ltd. (cogeneration) & 22 \\
Kinyara Sugar Works (cogeneration) & 7.5 \\
Kilembe Mines Ltd. (small hydro) & 5 \\
Tronder Power Bugoye (small hydro) & 13 \\
Eco Power Ishasha (small hydro) & 6.5 \\
Africa EMS Mpanga (small hydro) & 18 \\
Hydromax Buseruka & 9 \\
Kasese Cobalt Company Ltd. & 10.5 \\
\hline Total & 821.5 \\
\hline
\end{tabular}

Data Source: Ministry of Energy and Mineral Development, Uganda 2015.

Moreover, Uganda's energy development index (EDI), illustrated in Figure 3, indicates that there is a definite portion of the nation's population that does not have access to electricity [44,45]. Figure 3 also shows that the present total electricity access in Uganda is estimated at approximately $20.4 \%$ nationally, with only $10 \%$ in rural areas [44,45]. Consequently, Uganda presently has one of the lowest per capita electricity consumption totals in the world with $215 \mathrm{kWh}$ per capita per year compared to its neighbour, Kenya, with $355 \mathrm{kWh}$ per capita [45]. Also, this is not comparable to the average per capita of $552 \mathrm{kWh}$ for sub-Saharan Africa and $2975 \mathrm{kWh}$ per capita for the World [45].

However, the diversification of the energy mix of Uganda can help handle the present power situation in the country and meet a significant portion of its energy needs by increasing investment on other available RE resources, thus reducing the vulnerabilities affecting its hydro resources. If the solar and wind potential, for instance, is proven to be sufficient for commercial on-grid generation, then these technologies can become an important large-scale diversification option for the country. Nevertheless, since energy is a vital element for economic growth, industrialization, rapid urbanization and improving the standard of living, there is an imperative need for the government to enhance the potential use of Uganda's enormous RE resources to avoid stumbling into energy supply crisis in the nearest future.

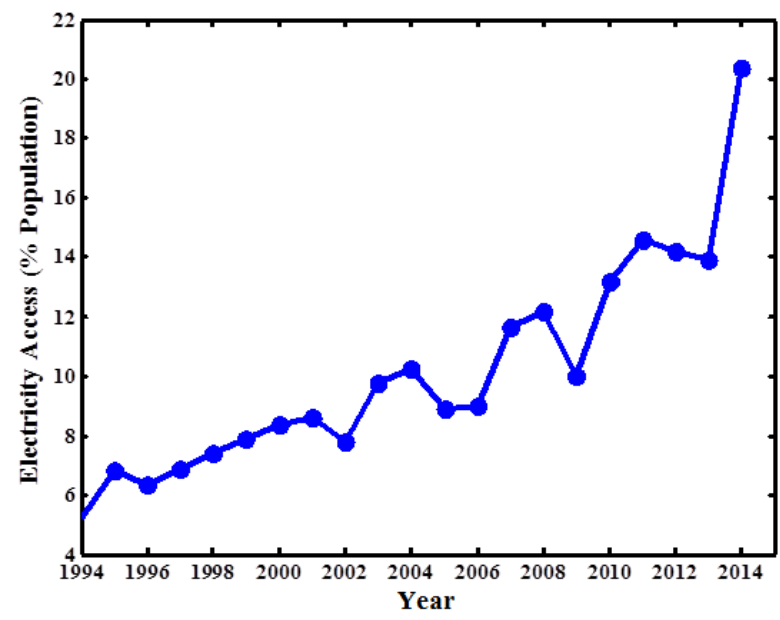

Figure 3. Total electricity access to electricity (\% population) in Uganda from 1994 to 2014. Data obtained from Ref. [45]. 


\subsection{Peat}

Despite the fact that peat is not really a RE resource, it is often considered alongside RE resources in some countries [46]. The peatlands area in Uganda is projected to be about $4000 \mathrm{~km}^{2}$, while the average thickness of peat deposits is estimated to be about $1.5 \mathrm{~m} \mathrm{[47]} \mathrm{and} \mathrm{the} \mathrm{total} \mathrm{peat} \mathrm{volume} \mathrm{to}$ be 6000 million cubic metres [47]. With respect to prior laboratory studies [47,48], the average dry bulk density is estimated to be around $100 \mathrm{~kg} / \mathrm{m}^{3}$ and a net calorific value of $17 \mathrm{GJ} /$ tonne while theoretically, peat volume corresponds to about 250 Mtoe (million tonnes of oil equivalent) [48].

Considering the erratic quality of peat and the Wetland Policy of Uganda, along with the possibility of using conventional peat production methods, approximately $10 \%$ of peat could most likely be used for power generation. Therefore, the available reserve of peat resources would be sufficient for a production capacity of about $800 \mathrm{MW}$ for the next 50 years or more [47]. Nevertheless, peat production units can be small (typically less than $20 \mathrm{MW}$ ) as a result of the dispersed nature of the obtainable fuel peat resources, and this is mainly distributed in Western and South-Western Uganda, where the desired resource features are better compared to other regions [49].

\subsection{Wind Energy}

Wind energy production is one of the fastest growing RE markets in the world today [50]. The global cumulative installed wind energy capacity has increased progressively from $6100 \mathrm{MW}$ in 1996 to approximately $487 \mathrm{GW}$ in 2016, surpassing the previous year by $12.6 \%$ [50]. It is thus anticipated that wind energy will play a vital role in the mitigation of future greenhouse gas emission [51]. Presently, 90 countries use wind to produce energy. Among this number, about 49 countries have increased their installed capacity between 2009 [52] and 2016 [50], nine with more than 10,000 MW installed and 29 have made/passed the $1000 \mathrm{MW}$ mark [50]. African and Middle Eastern countries have recorded an increase in installed cumulative capacity of $418 \mathrm{MW}$, with South Africa being the only country that had new installations, unlike in the previous year where three nations (South Africa, Ethiopia and Jordan) recorded a total increase of $773 \mathrm{MW}$ [50].

In most areas in Uganda, wind speed is considered to be moderate according to the meteorological record [43]. This is because it ranges from $2 \mathrm{~m} / \mathrm{s}$ to about $4 \mathrm{~m} / \mathrm{s}$ with an average of about $3 \mathrm{~m} / \mathrm{s}$, for low heights or flatter areas such as Lake Victoria area (less than $10 \mathrm{~m}$ ) [43]. Conversely, in some areas with complicated topography, the wind speed may increase to $6 \mathrm{~m} / \mathrm{s}$ as a result of slopes of mountainous and hilly areas such as the Karamoja region [43]. This can be seen in Figure 4 [43]. Based on the wind data collected by the Meteorology Department, Ministry of Water, Lands and Environment, of Uganda between 1989 and 1992 from 11 sites, the wind speeds in most part of Uganda are only adequate to run small wind generators of approximately $50 \mathrm{kWp}$ [43] for small-scale electricity generation and for special applications, such as water pumping. Prior study by Buchholz et al. [53] however, indicated that the wind speeds recorded by the Meteorology Department, Ministry of Water, Lands and Environment of Uganda may have been recorded at low metrological heights and not the standard $10 \mathrm{~m}$, suggesting that the wind routine may be much higher than stipulated [53]. The wind data collections from the national meteorological station were not carried out with the intention of measuring the wind speed for energy utilization. Further measurement carried out under the Alternative Energy Resource Assessment and Utilization Study at Kabale and Mukono between June 2003 and September 2003 suggested that the average wind speed for the two sites at a height of $20 \mathrm{~m}$ is about $3.7 \mathrm{~m} / \mathrm{s}$ [53]. The study concluded that wind energy resources in Uganda are insufficient for large-scale electricity generation. 


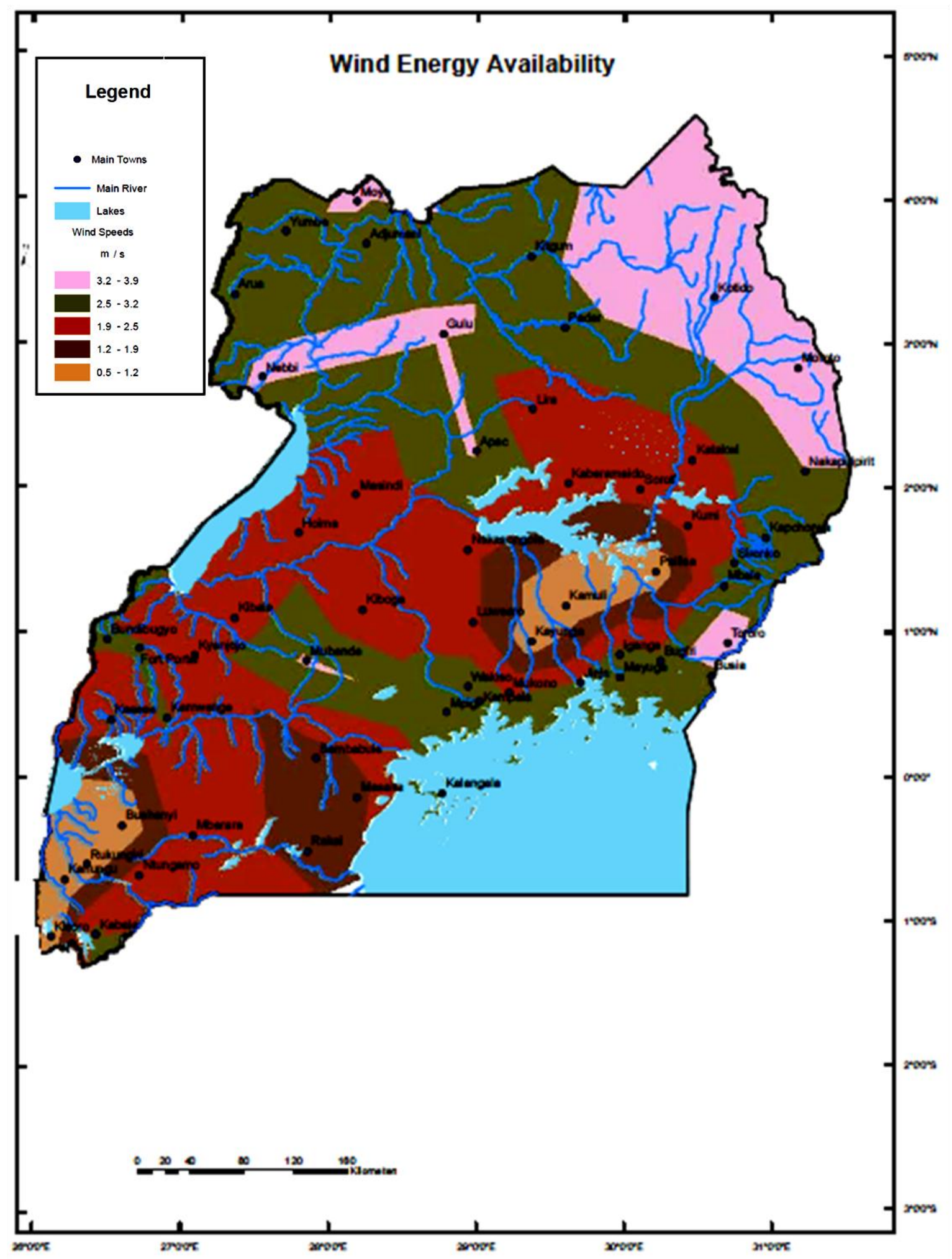

Figure 4. Map showing the availability of wind energy for different sites across Uganda. Data obtained from Ref. [43].

Recently, low-speed turbines have been developed and have proved to be effective for power generation [54], and recent studies [35,54-57] also confirm that electricity generation through wind is feasible, especially for small industries or in rural areas where targets for a mill range from 2.5 
$\mathrm{kV}$ to $10 \mathrm{kV}$ [56,57]. A study by Karekezi et al. [41] also indicated that the Karamoja Development Authority (KDA) and the Roman Catholic Mission, the Church of Uganda already have wind pumps installed in Karamoja in the north-eastern parts of the country [41]. There are some other parts of the country, such as Kalangala and some parts of Mubende etc., that have adequate wind which can also be harvested as a source of energy [41].

However, in many parts of the country, this technology has had low distribution rates. This has mainly been attributed to the initial costs involved, the lack of availability of the technology on the local market and the lack of awareness of the wind energy application [43]. Preliminary investigations have shown that there could be the potential for production of electricity on a medium scale. In this regard, the Government of Uganda (GoU), in its plans to implement a systematic wind mapping program through the Ministry of Energy \& Mineral Development, recently acquired some wind measurement equipment which is currently being installed at high altitudes in the Napak and Kotido districts of the Karamoja region $[35,43]$. The project is geared towards the collection of consistent and relevant wind data to determine the best delivery method for this technology in the regions that are considered to be endowed with wind.

\subsection{Solar Energy}

Solar energy is the most promising and abundant RE source in Uganda (See Figure 5) [43,58]. It is the fundamental energy resource that drives other RE sources such as biomass, hydropower, wind etc. [20,59-61]. Solar energy is an alternative source of energy in rural and remote communities whose connection to the national grid may not be economical [19,61-63]. It can help reduce rural-urban drift and supplement the swift growth of small-scale industries [64,65].

The current solar data [43] clearly reveal that solar energy resources in Uganda are located along the equator, and this allows Uganda to obtain a high level of solar insolation of about $8 \mathrm{~h}$ of sunshine daily, all through the year [43]. The electromagnetic radiation from the sun is estimated to be approximately $6 \mathrm{kWh} / \mathrm{m}^{2} /$ day in the country [43]. The solar insolation value is favourable for various applications and technologies that may include solar thermal electric power generation [66], solar water heaters [67] (one of the most cost-effective solar applications), solar photovoltaic (PV) power generation [68,69], and solar houses in building applications [69].

Although the use of solar PVs in Uganda started in the early 1980s, the current solar energy installation in the country is relatively low [70]. The early utilization of a solar PV system in Uganda was primarily motivated by funds from donor programmes and government institutions for lighting and vaccine refrigeration in health centres [70]. The Uganda Railways Cooperation installed about $35 \mathrm{~kW}$ of solar PV in 29 locations for communication and signalling while the Uganda Post and Telecommunication Cooperation also installed $30 \mathrm{~kW}$ at 35 telecommunication sites in remote areas across the country as an earlier initiative [71]. By 1992, the total capacity of PV installation became $152.5 \mathrm{~kW}$ with at least $538 \mathrm{PV}$ installations across the country [71]. These were mainly used by the Ministry of Health and other government agencies [70,71]. Karekezi et al. [41] reported that there were $238 \mathrm{PV}$ vaccine refrigerators recorded in that same year, amounting to about $60 \mathrm{~kW}$ of installed capacity. The authors also indicated that, in 1998, an increment of 962 solar PV installations in the country, which include 300 community-based systems that were funded by external donor agencies, was recorded [41]. 


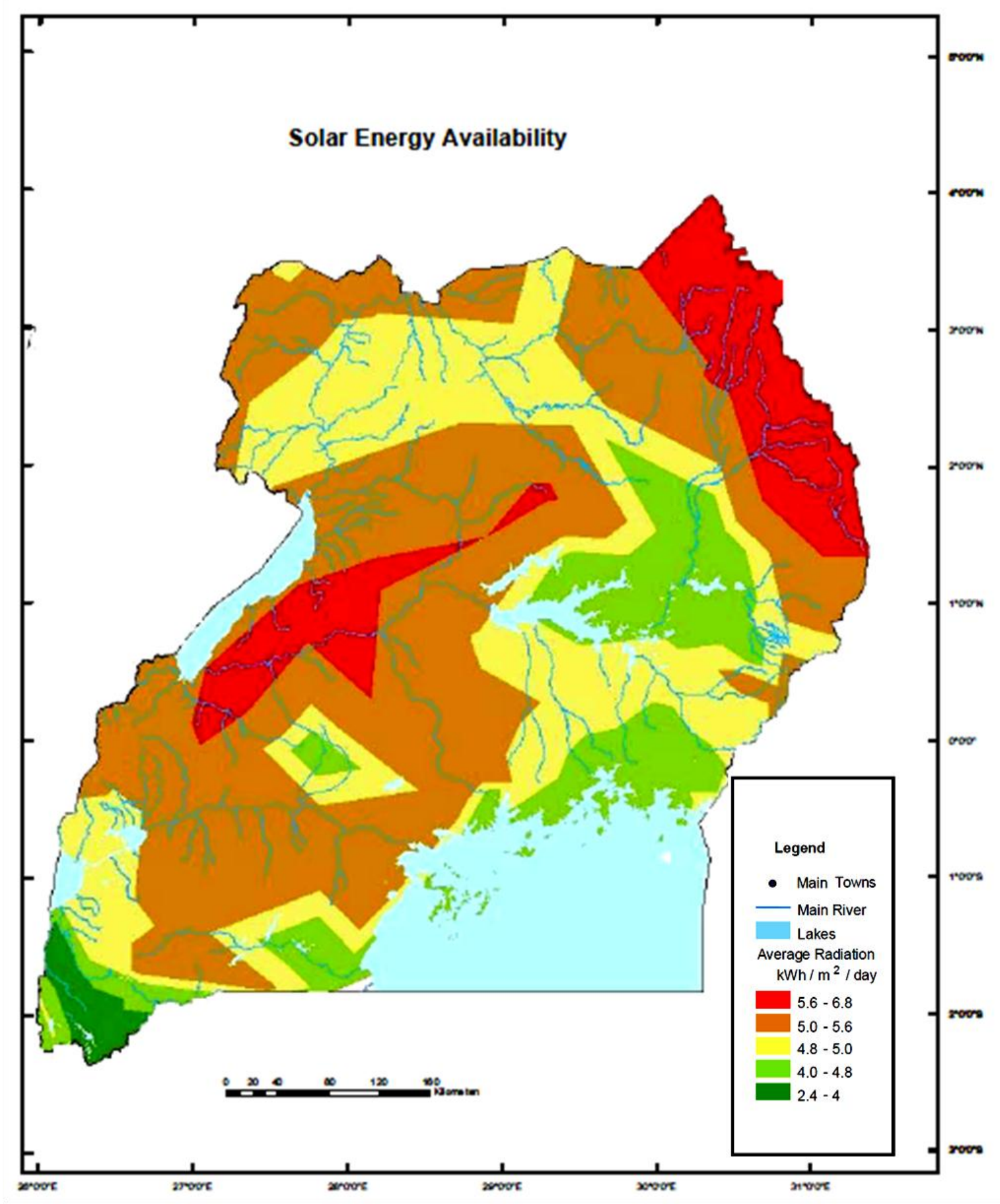

Figure 5. Map showing the availability of solar energy for different sites across Uganda. Data obtained from Ref. [43].

Following this improvement and the introduction of Chinese and Taiwanese silicon solar PV products [72,73] (70\% of all solar cells and modules presently sold in the world [74]), the GoU launched the Rural Electrification Strategy and Plan (RESP) in 2001. The RESP was designed to run from 2001 to 2010; however, it elapsed in 2012 due to delay in implementation [75]. Although the project was geared toward increasing the use of solar PV in rural areas, the RESP could not meet with expectations. The RESP could only install 7000 systems out of the anticipated 80,000 systems. This was a huge failure, as only $8.75 \%$ of the expected outcome was achieved despite the timeline of 11 years [76]. 
However, as a result of the attractive feed-in-tariff (FiT) scheme and the announcement of the proposed construction of eight RE projects of about $83.7 \mathrm{MW}$ in early 2014 by the Electricity Regulatory Authority (ERA), more foreign investors are now entering into the solar PV market in the country [35]. These include the Solar Energy for Africa firm, which is presently exploring a 50 MW solar thermal plant that is located in the Namugoga area of Wakiso District [77], and recently, an on-grid solar/diesel system project of 1.6 MW installed capacity was sponsored to completion by the Kalangala Infrastructure Services in order to service the residents of Kalangala Island [78].

On the other hand, the majority of the installed solar PV systems in the country are mostly achieved through government- or donor-supported projects [43]. The core driver of most of the government introduced projects is the World Bank-supported rural electrification program, tagged "Energy for Rural Transformation (ERT)" [74,76]. Presently, the number of solar PV systems for both institutional and home based-systems in the country can be estimated to be over 30,000 PV installations, now accounting for 1.25 MW installed capacity [74]. This is gradually being distributed in the rural areas. Furthermore, there have been significant efforts to create more awareness for the use of solar energy and small PV systems in the country. A major player in the sensitization process is the Joint Energy and Environment Projects (JEEP) Uganda Nordic Folk centre for RE, an Non-governmental Organisation (NGO) from Denmark that has created awareness for RE in areas such as Tororo, Luwero, Arua etc. [79].

\subsection{Geothermal Energy}

Geothermal energy is one of the probable alternative RE sources in Uganda that can complement the existing sources of energy [71,80]. It is an eco-friendly and multipurpose RE resource that can support different developmental activities, ranging from raw material production and processing to mineral and agricultural production [81]. Scouting surveys in Ugandan geysers was begun in 1921 by the geological survey of Uganda [71]. The initial results from the survey were published by Wayland in 1935. With the supports of the United Nations, further efforts were made in 1973 to start a geothermal project as a result of the oil crisis during that period. However, this was not achieved due to the political chaos in the country [82].

In spite of the fact that geothermal energy is still in the exploration stage, and has been since 1993, over 40 geothermal sites have been studied to explore potential parameters/tectonic and volcanic features such as the reservoir temperature, chemistry of reservoir, ground permeability, and natural heat transfer [82]. Figure 6 shows the identified geothermal sites in Uganda (data obtained from the Energy Sector Geographic Information System (GIS) working group) [83]. These investigations have so far identified three major potential areas that are located in the western branch of the East African Rift Valley in western Uganda [43,82]. These include Katwe-Kikorongo, Buranga and Kibiro. They were found to have high potential for the development of geothermal power generation, with an estimated geothermal energy potential of $450 \mathrm{MW}$ in total [35,42]. The results from prior studies [80-82] also indicate that the temperature level ranges between $150{ }^{\circ} \mathrm{C}$ and $200{ }^{\circ} \mathrm{C}$, which is adequate for electricity generation and for direct use in industry and agriculture. Nevertheless, some of the other sites such as Panyimur and Kanangorok will still require further surface testing to provide more guidance on the best exploratory options [35]. 


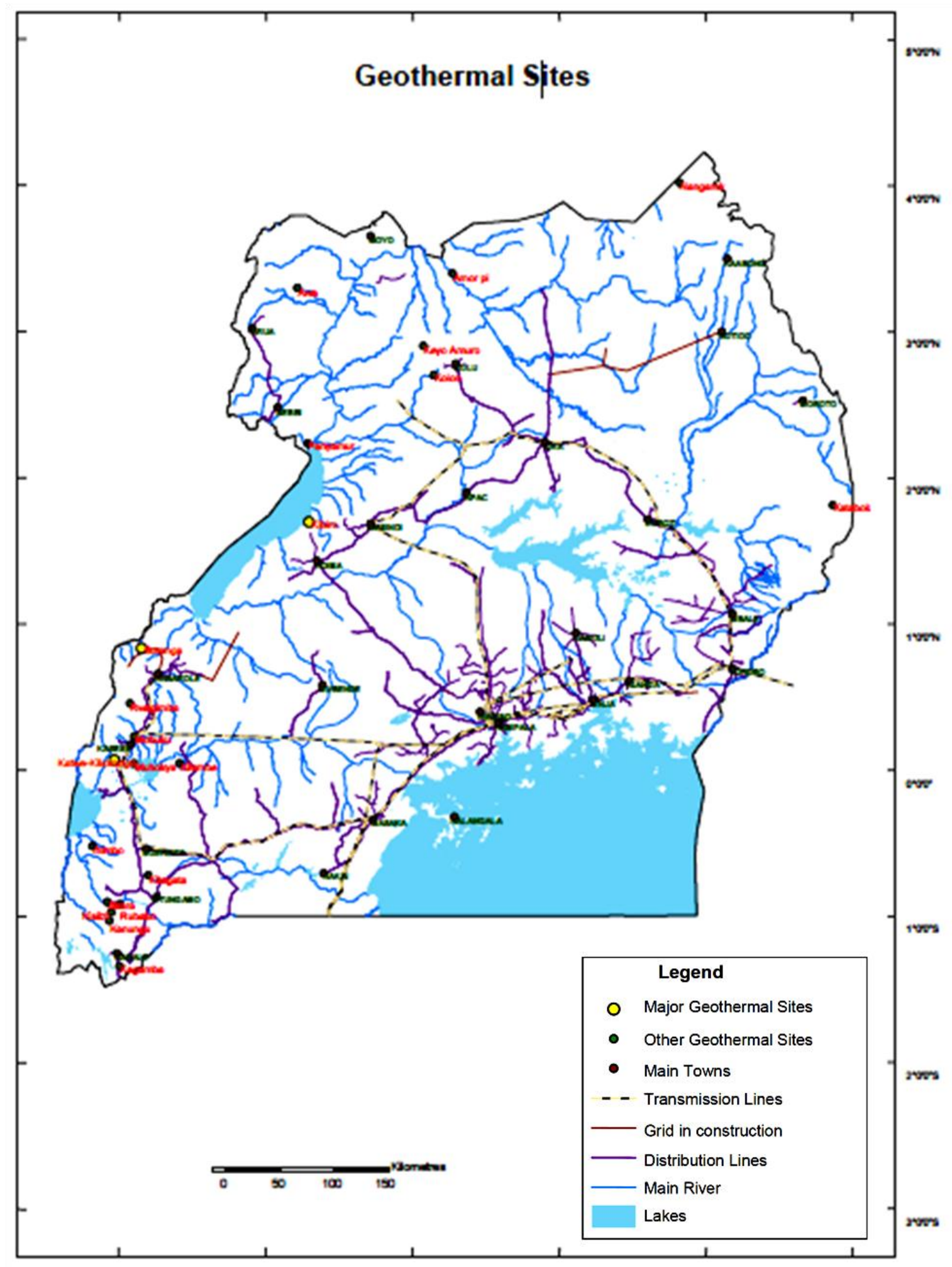

Figure 6. Map showing the identified geothermal sites country-wide in Uganda. Data obtained from Ref. [83].

Furthermore, the efforts of the GoU are currently focused on the development of the aforementioned area to a viability stage that will help acquire essential data for feasibility study [35]. Further studies are also presently being carried out across other identified geothermal areas in the 
country. These preliminary studies involve the drilling of deep exploration wells that will help provide information on reservoir temperature, fluid chemistry and other petrophysical parameters [35]. The results from these studies will soon be made available.

\subsection{Hydroelectric Energy}

With the support of the Japan International Cooperation Agency (JICA), a hydropower development master plan has been developed with the potential of hydro resources estimated to be over $4100 \mathrm{MW}[35,84]$. The large-scale hydropower potential is located near the River Nile which originates from Lake Victoria. The flow of the River Nile is controlled by the Owen Falls Dam (now Nalubale Power Station), a hydropower station constructed in the 1960s $[85,86]$. The station initially had 10 generators with a total installed capacity of $150 \mathrm{MW}$ before it was refurbished and upgraded to $180 \mathrm{MW}$ alongside the construction of a new $200 \mathrm{MW}$ power station in Kiira [86].

However, with the economic liberalization and the unbundling of the electricity utility, both Nalubale and Kiira hydropower stations were leased to Eskom (U) Limited under a 20-year concession agreement [87]. As a result, the two hydropower stations became the back-bone of the electricity distribution network in the country. A new 250 MW hydropower facility at Bujagali was completed in 2012 and started operation in the same year. The current total installed capacity of hydropower in Uganda is about $690 \mathrm{MW}$, and this is basically generated from Nalubale Hydropower Station at Jinja in South-Eastern Uganda. Nevertheless, during droughts (such as in 2009), only about half of the installed capacity would be utilized. This is as a result of the low water level experienced in Lake Victoria during this period. Another barrier to electricity supply is the increasing growth in demand for electricity which has not been matched with present generation capacity. To alleviate this problem, the government mandated UMEME to operate, maintain, upgrade and expand the distribution network, trade electricity to its customers and to improve energy efficiency (EE) with the electricity distribution system [88].

\subsubsection{Large-Scale Hydropower}

The installed capacity for large-scale hydropower that is operational to date is $630 \mathrm{MW}[35,43]$. These include the Nalubaale Power Station with a capacity of 180 MW, Kiira Power Station with an installed capacity of $200 \mathrm{MW}$ and the Bujagli Power Station with an installed capacity of $250 \mathrm{MW}$. In addition to the operational hydropower stations, three large hydro power stations have been appreciably studied and are presently being developed on a public-private partnership (PPP) basis in order to produce electricity in the medium term [43]. These stations include the Isimba Power Station with a capacity of 183.2 MW [43] and expected to be operational in 2018, the Karuma Power Station with a capacity of $600 \mathrm{MW}$ [43] and expected to be operational in 2018, and the Ayago Power Station with a proposed size of $600 \mathrm{MW}$, which is expected to be operational in 2023. Other major potential sites for hydropower that are yet to be developed include Kalangala with a potential capacity of $450 \mathrm{MW}$, Oriang with a potential capacity of $400 \mathrm{MW}$, Kiba with a potential capacity of $300 \mathrm{MW}$ and Murchison Falls with a potential capacity of $600 \mathrm{MW}$ [43]. This implies that the untapped potential of large-scale hydropower in the country is about $1750 \mathrm{MW}$. Figure 7 shows the large hydropower sites nationwide in Uganda $[43,83]$. 


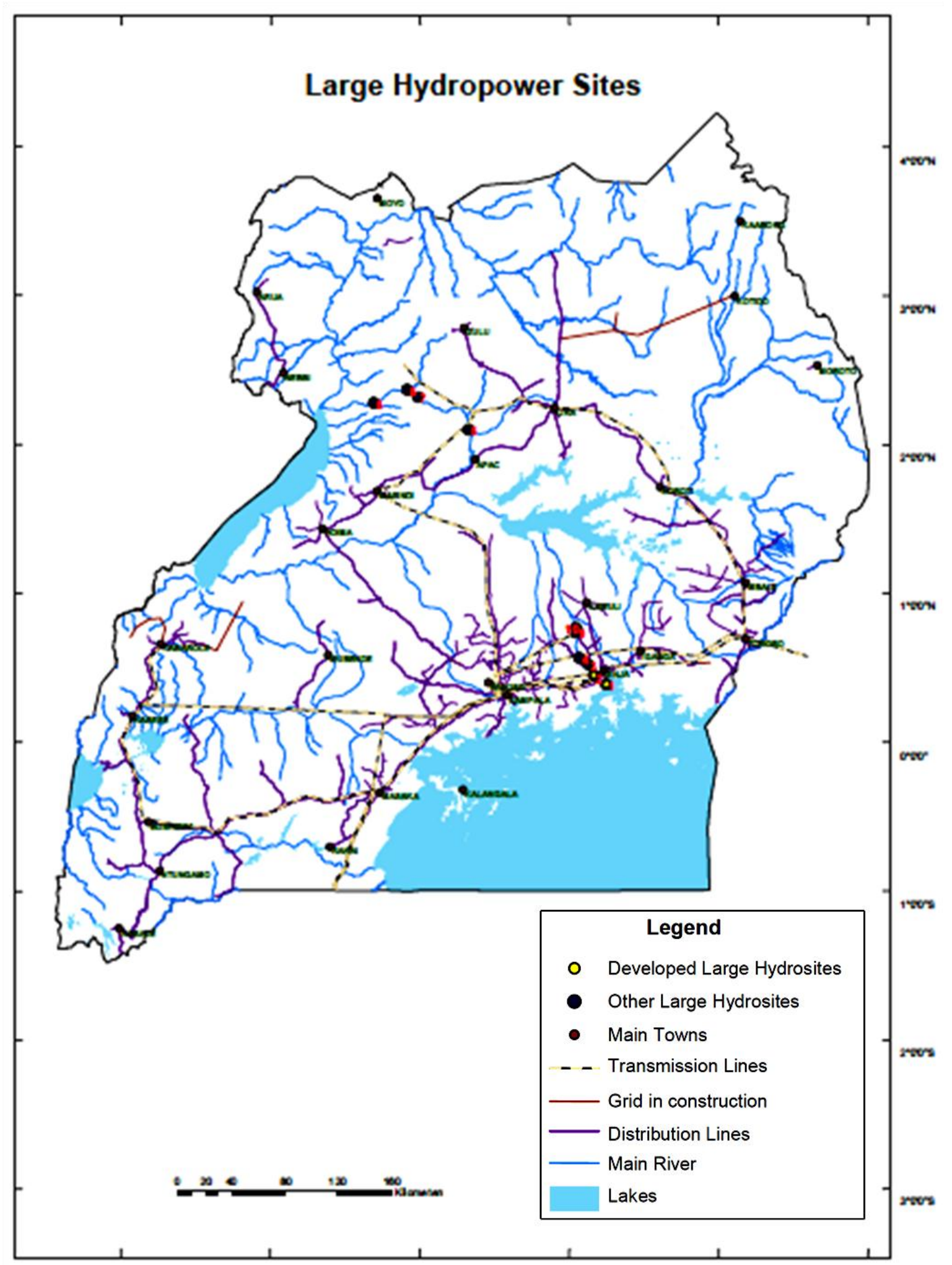

Figure 7. The identified large hydropower sites country-wide in Uganda. Data obtained from Ref. [83].

\subsubsection{Small- and Medium-Scale Hydropower}

Unlike large-scale hydropower, the small- and medium-hydro sites are not located on the Nile, but they also possess potential resources which are yet to be fully exploited [35,43]. These sites 
are majorly located in the Western and the Eastern regions of the country which are hilly and mountainous [86,87]. About 50 potential sites have been identified near rivers for small hydropower. The total potential capacity is estimated to be $164 \mathrm{MW}$ of electricity [87]. Some of these small hydropower stations that are operational include the Kuluva $(120 \mathrm{~kW})$, Kagando $(60 \mathrm{~kW})$ and Kisiizi $(300 \mathrm{~kW})$ which supply electricity to isolated hospital grids.

Furthermore, a total of 59 medium hydropower sites with a total potential of approximately $210 \mathrm{MW}$ electrical capacity have been identified via various studies in the country [35,43]. Some of the sites have the potential to be used for isolated grids, while others can be used for energy supply to the grid [35]. Some of these sites include the Kanungu Power Station of Eco Power with 6.4 MW capacity of electricity, and Mpanga Power Station of Africa Energy Management Systems which has $18 \mathrm{MW}$ installed capacity of electricity. The combined installed capacity for small-scale and medium-hydropower that is operational to date is $53 \mathrm{MW}$ [43].

\subsection{Biomass Energy}

Basically, biomass means any available organic matter that is renewable through photosynthesis $[89,90]$. In the context of energy, biomass may mean products containing partial/full vegetable matter that are derived from agriculture or forestry [27,91,92]. They can be used as fuel with the intention of recovering their energy content. Biomass includes but is not limited to shrubs, grasses, crop residues, forest waste and agro-industrial residues. Currently, biomass is the leading type of energy used in Uganda, constituting about $94 \%$ of the total energy consumed in the country [33]. Biomass is the major source of energy for rural industries, and its trade contributes to the rural economy in terms of employment, rural incomes and tax revenue [93-95]. Charcoal is mostly used in urban settings while firewood, agro-residues, crop residues and wood wastes are broadly used in the rural areas $[33,94]$. The consumption of charcoal is increasing at a rate of $6 \%$ per annum and this has contributed to the degradation of forests as wood reserves are depleting at a rapid rate in many regions of the country [96]. Apart from fuel wood, wood is similarly used for paper products, plywood, electric poles and sawn-wood. However, the consequence of this is the continuous falling of trees which can lead to an ever-increasing problem of soil erosion and desert infringement if left unchecked [96]. Efforts are being made by the Ministry of Energy and Mineral Development (MEMD) with the support of some foreign NGOs (such as Deutsche Gesellschaft für Internationale Zusammenarbeit (GIZ)) to promote the use of the improved Rocket Lorena Stoves among households and institutions and thus reduce deforestation and the use of wood fuel [97]. The rocket stoves for households were locally made out of materials that can be acquired cheaply or at no cost in order to produce efficient stoves that fit the socio-economic setting of the poor living in the rural areas [97-100]. Since 2005, over 500,000 of this product has been successfully distributed in places such as Rakai and Bushenyi districts in Uganda [100]. Although about 10\% of all household in Uganda has benefited from the dissemination strategy/program $[97,100]$, more awareness about the importance of the affordable and acceptable biomass stoves needs to be promoted among the masses if the consumption of fuelwood must be reduced in the rural/urban areas $[96,100]$.

Furthermore, biomass is absolutely a vital RE source, but the sustainability of its production is not yet clearly understood. Uganda, like some other African countries, has numerous biomass resources (See Figure 8) that include rice husk, municipal waste, woods, oil palm products and sugar husk which can be used for the production of biogas energy. Table 3 shows the various biomass resources and their estimated quantities in Uganda [43]. On the other hand, the plant biomass can also be used as fuel for small-scale industries and could also be fermented by anaerobic bacteria to produce a multipurpose and cheap biogas which can be used for cooking $[43,101]$. Detailed information can be found in Ref. [101]. 


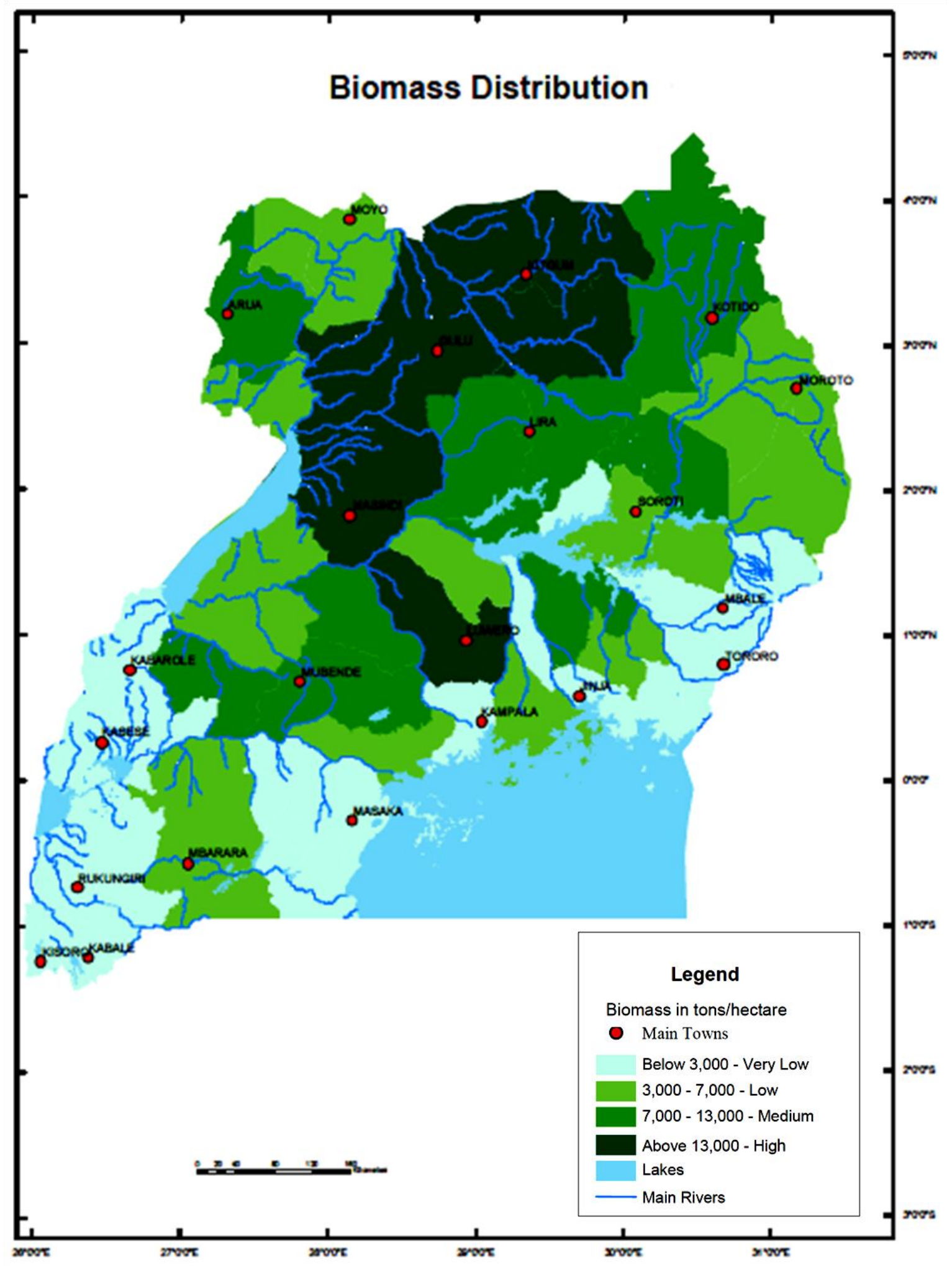

Figure 8. Map showing the biomass sites country-wide in Uganda. Data obtained from Ref. [43]. 
Table 3. Energy production potential from agro-residues.

\begin{tabular}{ccc}
\hline Biomass Type & $\begin{array}{c}\text { Estimated Annual Production } \\
\text { ('000 Tons/Year) }\end{array}$ & MWe Average \\
\hline Bagasse & 590 & 67 \\
Bagasse surplus (available immediately) & 50 & 16 \\
Rice husks & $3 \times 25-35$ & 30 \\
Rice straw & $45-55$ & 20 \\
Sunflower hulls & 17 & 1 \\
Cotton seed hulls & +50 (being developed) \\
Tobacco dust & $2-4$ & 2 \\
Maize cobs & 234 & 95 \\
Coffee husks & 160 & 37 \\
Groundnut shells & 63 & 407 \\
\hline
\end{tabular}

Data Source: Ministry of Energy and Mineral Development, Uganda 2015.

Currently, pine trees (33\%), eucalyptus (50\%) and cypresses (17\%) are the main sources of hardwood plantation in the country $[33,96]$. The total standing biomass stock is estimated to be 284.1 million tons with a potential sustainable biomass supply of 45 million tons [33]. Nevertheless, the sustainable wood that is within reach for biomass supply stands at 26 million tons, and this can only meet about $59 \%$ of the total demand of 44 million tons per year. Theoretically, the probable production of agricultural residues falls between 1.19 million tons to 1.2 million tons annually [102].

Apart from the sugar companies that utilize their sugarcane residue to generate electricity and heat, the use of other biomass such as coffee husks, rice husks etc. has not been fully explored in Uganda [43]. On the other hand, smaller cost-effective biogas technologies have been introduced to bolster the access to electricity in poor communities and have spread across five districts across Uganda [43]. They include Iganga, Kabarole, Mbale, Mpigi, and Tororo. A total of 50 biogas plants have been installed at an average of 10 per district, which is still a small number when compared with the number of districts in the country. Nevertheless, more efforts are required by the GoU to spread this technology across the remaining 116 districts.

\subsection{Biomass Cogeneration}

Cogeneration is one of the energy production technologies where biomass can be used as a form of clean energy [103]. Biomass cogeneration systems are systems with a combined heat and power (CHP) technology that simultaneously generate two or more forms of energy such as electricity, mechanical energy and thermal energy in a single or integrated system $[104,105]$. This is comparable with the common practice in Uganda, where electricity is produced from central power plant and on-site heating and cooling equipment that are used to meet non-electric energy needs [106]. The thermal energy retrieved in a cogeneration system can be used for heating in industry or buildings.

Currently, the installed capacity of a cogeneration plant is estimated to be approximately $30 \mathrm{MW}$, and most of them run with bagasse as fuel [33]. Some notable factories that utilize cogeneration for electricity production in the country include Kinyara Sugar Works Limited, Kikira Sugar Works Limited and Sugar Corporation of Uganda Limited. This implies that there is a substantial potential of cogeneration in the sugar processing industry.

Furthermore, any system that requires both electrical and thermal energy (e.g., cement and iron production, beer production, and foods and beverages processing among others) has the potential of exploring the modern cogeneration technologies [27]. However, the potential of the sugar industry alone is presently estimated to be more than $100 \mathrm{MW}$, whereas the combined potential capacity for the other industries is estimated to be around $50 \mathrm{MW}$ [33]. 


\section{The Motivations and Barriers to Renewable Energy Applications and Development in Uganda}

In an effort to meet with energy needs, following the ever-increasing population growth and socio-economic activities, the planned Uganda Vision 2040 envisioned an increase in the country's electricity production from the $822 \mathrm{MW}$ that had been attained since 2012 to $2500 \mathrm{MW}$ in 2040 [43,77]. The target contribution from renewable resources by the MEMD for 2040 is 2000 MW installed capacity, and it is anticipated that a greater portion will be from large-scale hydropower development [43]. This really demonstrates the government's aspiration to increase electricity generation while integrating renewable technologies into the country's energy mix. Moreover, RE development can convey key benefits for economic and social development, particularly in rural areas, via diverse applications. The development and applications of RE can thus be driven by many factors as discussed in Section 3.1. Nevertheless, RE development also faces many obstacles in Uganda, as in any other African countries. Some of these barriers affecting the scale-up of RETs in Uganda are presented in Section 3.2.

\subsection{Drivers for Renewable Energy Development in Uganda}

Aside from the advantage of having considerable RE resources for energy production and provision of energy services across the country, there are several other drivers propelling the development of RE in Uganda. These driving forces for investments in RE development are as discussed below.

\subsubsection{Energy Demand}

In Uganda, as in any other country in the world, the energy sector is the engine for economic growth and development and it plays a vital role in the welfare of its citizens. Likewise, electricity is one of the most significant forms of energy that provides essential input into all the other sectors of the economy. The energy consumption pattern in Uganda can be divided into five major sectors, namely household, commercial, industrial, agriculture, and transportation sectors [43]. Over $79.6 \%$ of the population does not have access to electricity, and household electricity access is currently the lowest in Uganda [44]. Due to this high demand for energy, Uganda presently suffers from an inadequate supply of energy despite her abundant energy resources [44,106]. This implies that the rapidly growing demand for energy in the country is expected to create opportunities for RE development in the nearest future. Furthermore, the expanding economic opportunities in rural areas will also demand an assertive deployment of RETs [107].

Moreover, population growth is a key driver of energy demand and the population projection of Uganda is expected to grow from 39.03 million in 2015 to 61.93 million by 2030 at an average annual rate of 3.3\% between 2018 and 2030 [108,109]. Thus, there is a need to increase investments in RE projects in order to respond to the increasing growth in population and energy demand.

\subsubsection{Reduction of $\mathrm{CO}_{2}$ Emission/Footprint}

Energy is essential for development and human livelihood [13]. However, the production of energy has been associated with the increase in atmospheric greenhouse gas emission (GHE) concentrations [110]. Comprehensive details can be found in the Intergovernmental Panel on Climate Change (IPCC) Fourth Assessment Report (AR4) [111]. For example, the rapid rise in combustion of fossil fuel has produced a corresponding rapid growth in $\mathrm{CO}_{2}$ emissions $[110,111]$ and RETs serve as one of the many options and combinations that are possible for the reduction of these emissions [111].

Thus, the need for climate protection is one of the main factors that have supported the continued increase in the use and development of RE in Uganda [112]. Despite the fact that the use of RE is still comparatively small, its growth has increased rapidly in recent years. Also, desertification is one of the aftermaths of the change in climate as driven by hasty greenhouse emissions [110]. This is because most RETs produce no/low specific emission of $\mathrm{CO}_{2}$ into the atmosphere relative to fossil fuels, thus making them valuable tools for addressing climate change. As a result, energy generation 
through different RETs will thus reduce the industrial carbon footmark and will also be a superb measure of decreasing the emission of $\mathrm{CO}_{2}$, thereby extenuating climate change across the Uganda, particularly in the northern region of the country. In addition, the lowering of the water table in the northern region of Uganda through desertification [112] will continue to also make some RE applications like solar water pumps a significant choice for the supply of water.

\subsubsection{Energy Sector Reforms}

The endorsement of the energy policy (power sub-sector reform programme) by the GoU in 2002 made provision for the introduction of diversification in the nation's energy mix [43,113-116]. The reform programme aimed at providing a sufficient, consistent, and cost-effective power supply to meet the country's demand, promoting the efficient operation of the power sector and scaling up rural and sub-urban access to maximize the impact on poverty reduction. This has led to the implementation of major structural change in the sector. The energy policy also made way for the establishment of a renewable energy policy (REP) which aims to increase the use of modern RE in the energy mix of the country $[113,115]$.

Furthermore, the Ugandan Government's Poverty Eradication Action Plan (PEAP) also has energy as an integral part of its plan due to the recurrent recommendation to link poverty alleviation and energy $[43,113]$. This is planned to be attained through grid extension, public and private sector involvement, mini-grids, and stand-alone electrification systems for rural/urban areas. The National Development Plan (NDP) that was launched in April 2010 by the GoU also dealt with a number of energy issues that can guide the increase of electricity access and consumption for growth, employment and socio-economic change.

In general, these reforms have resulted in the deployment of considerable private resources for investments, amendment in power-systems planning, and increase in levels of expertise and financial transparency in the sector [113]. RETs will thus play a vital role in attaining these plans in both on-grid and off-grid systems owing to the enormous energy resources in the country.

\subsubsection{Energy Security and Access for Rural Electrification}

Presently, electricity supply in Uganda is unequally distributed across the country, and yet the limited electricity supplies have been limited to majorly urban and semi-urban areas [44]. Since electrification access in Uganda is still very low, at approximately $20.4 \%$ nationally and $10 \%$ in rural areas [44], the electrification of most parts of the country through grid extension in the near future is still not visible. As a result, the GoU is stimulating decentralization and models for off-grid power supply for remote communities. The majority of these cases require the deployment of the available RE sources in the vicinity of the communities (such as small hydro, solar energy, wind and biomass resources) to meet the electricity needs of the people.

The commitment of the Ugandan Government to expand the use of RE sources is clearly targeted at generating a path for socio-economic development, particularly by transforming rural communities [106,114]. RE technology is thus a stabilizing factor for energy generation and supply in Uganda. RE developments will therefore be a highly probable source for diversifying the energy mix and increasing the share of household energy supply in the country, thereby meeting the aim of security of supply.

\subsubsection{The Need for Employment Generation}

Promoting RETs across Uganda will play a vital role in the reduction of poverty as local communities will benefit from employment opportunities, skill acquisition, investment opportunities and technology transfer. Several RE preliminary projects in the least developed countries, such as Uganda, provide subjective evidence of the roles played by RETs in energy-poor communities [117]. Consequently, an increased investment in RE applications and technologies will lead to the development of indigenous expertise in installations, repairs, and local manufacturing of the different 
RE components/devices across the rural communities, off-grid communities, and the whole country at large, therefore, leading to the massive generation of employments.

\subsubsection{Economic Impact}

Currently, RETs are considered not only as means for improving energy security and mitigating and adjusting to climate change but are also gradually recognized as investments that can offer direct and indirect economic intrinsic worth by cutting down the reliance on imported fuels, improving the quality of local air and safety, increasing energy access and security, creating jobs, and driving economic development [118]. The remarkable growth in RE markets and their wide spread globally has also guided the significant growth of its manufacturers, scale of production, and job creation in term of installations and servicing of RETs such as solar PV and wind energy industries [118].

Thus, by recognizing that RE is a major driver of socio-economic development, Uganda designed its investment plan (IP) to exploit the country's policy infrastructure for sustainable energy that is envisioned in its Vision 2040 for Uganda [119,120]. This includes an unwavering 80\% increase in energy access by 2040, especially for remote and isolated areas, where power connection to the main grid is considered to be too expensive [120].

Furthermore, for some time now, Uganda has made a commitment to this IP in response to the urgent need to address the problem of energy access as part of the nation's vision for a prosperous Uganda. As a result, in November 2015, Uganda's extensive IP received a booster when the Climate Investment Funds (CIF) endorsed the country's IP to transform its energy resource through RETs including geothermal, solar and wind technologies [121].

\subsubsection{Energy Efficiency}

EE is an initiative designed to ensure economical use of energy in all sectors of the economy: i.e., the use of less energy to provide the same amount of service or useful output $[122,123]$. RETs tend to have a greater visibility than EE programs. However, one of the advantages of adopting RE is the resultant increase in the awareness of energy production and consumption in the owner of the installation and also repeatedly with the public who possibly can see or interact with the technology. A good example is the public awareness of RE raised when a solar PV or solar water heating panels is installed on a public building.

Although Uganda has a low rate of electrification at about $25 \%$, the electricity that is generated is repeatedly used inefficiently, therefore grating the already insufficient supply. This situation has caused Uganda to be one of the world's lowest energy consumers. However, in 2012, Uganda opted-in and became one of the 14 primary movers of EE for Africa. As a result, EE standards for five selected appliances, namely air conditioners, lighting appliances, electrical motors, freezers and refrigerators, were developed in order to provide universal access to energy, increase EE and increase the use of RE. The importance of EE standards as a policy objective can be linked to commercial and industrial competitiveness, energy security benefits, and increased environmental benefits (such as reduction of carbon dioxide emissions) [124]. Generally, improved EE leads to reduction in operation costs in most businesses, thus allowing "energy efficient" companies to gain advantage over those that are not energy efficient.

\subsubsection{Feed-in-Tariffs}

In order to advance the development and use of RE sources, the GoU, along with some other African countries such as Kenya, Tanzania, Rwanda, Algeria, Mauritius, Egypt and South Africa, developed a FiT structure that now serves as an instrument for disseminating private sector generation of electricity from RE sources $[125,126]$. This has encouraged both individual investors and companies to invest in the generation of RE in Uganda [125,126]. Furthermore, the scheme has increased the financial support base for RE generation and motivated the rapid sustainable development of RETs in 
the country. However, a proper implementation of the RE FiT policies can offer a competent mechanism that can fully unravel RE development in Uganda.

\subsection{Major Barriers and Challenges of Renewable Energy Development in Uganda}

In order for the GoU to meet with its commitment to achieving the energy needs of its people and promote RE in the national energy mix, a number of barriers will have to be addressed. The following are thus considered as the barriers and challenges that may prevent the steady growth of RE development and its utilization in Uganda.

\subsubsection{Lack of Information and Public Awareness}

The lack of public awareness has been known to be a main barrier in the utilization of RETs in many countries $[127,128]$. The most common issues associated with this are inadequate knowledge regarding the use, importance, socio-economic and environmental benefits that are derivable from RE and its technologies [127,128], and the fears in relation to the economic feasibility of RE installation projects. Because RETs are relatively new in Uganda, a large number of the public sector knows nothing or little about them $[61,129]$. Also, the public sector is not provided with adequate and sufficient training required to make informed choices (i.e., there is a deficiency of technical information). The absence of vital information and proper awareness has generated a disparity in the RE technology market that has given rise to a higher risk perception for potential RE prospects [130,131]. However, the accessibility of such vital data could increase investors' interest and thus RE project development.

\subsubsection{Huge Initial Investment Cost}

A critical barrier to the development of RE technology in Uganda as a less-developed country resides in the high initial investment and installation costs of RE equipment [131]. The high initial cost may also be a key contributing factor to continued investor confidence and an overall inadequacy of financing tool as well as uneven financial sectors [131].

There are little or no incentives for local manufacturing or importation of RE technology such as solar devices in Uganda. Although the PV panels are duty free (except for value added tax (VAT)), other solar PV components such as batteries and DC lamps still attract up to $24 \%$ import duty. This has increased the cost of investment in RE equipment and devices above other traditional energy technologies. As a result, some RE projects such as solar are executed using sub-standard or fake solar PV system components. For instance, some solar project contractors (e.g., solar street lighting systems) mostly have a preference to save costs by ordering components that are of a low quality/standard, and as a result, many solar PV projects fail within a short period after they are installed or commissioned. It is therefore very difficult for an average Ugandan/company to invest in RE technology systems.

\subsubsection{High Operation and Maintenance Cost}

RETs are considered to be alternatives for the supply of electricity to urban, rural and remote areas in Uganda $[130,131]$. However, the maintenance and operation costs of the RETs is noticeably high in the country [131]. This is as a result of inadequate technically skilled human resources and limited institutional capacity in both the private and public sector that can execute and manage RE infrastructures. For example, in spite of the fact that $85 \%$ of the Ugandan population live in rural areas, there are only a few public and private sector enterprises that are involved in the energy business in these communities $[130,131]$. Hence, possible RETs users in the remote communities are hindered from increased participation and benefits, which would have arisen from suitable RE interventions. 


\subsubsection{Inadequate Attention to Research and Development}

Presently, the GoU has not given proper attention to research and development in the subject area. There is a lack of focus on research and development in the RE, and there is not any visible plan/budget provided to universities and institutions of higher learning to precisely conduct research on RETs [132]. That is, there is no well pronounced RE research and development program that is supported with modest funding. Also, no working systems have been put in place for quality international research and development collaborations that can easily accelerate transferable skills and technologies. The negligence of this overall technically supportive environment has slowed down the development of most RET projects such as solar and wind energy technologies [132,133].

As a result, domestic technical knowledge concerning these products is inadequate and, as such, related technologies are imported at very high cost. However, with an indigenous skilled and averaged-skilled workforce, a sustainable RE industry in Uganda can be easily achieved. This implies that skilled personnel from multidisciplinary academic and research institutions are mandatory for R\&D activities in Uganda.

\subsubsection{Lack of Human Capacity \& Training}

Developing a skilled workforce to operate and maintain RET equipment is essential for a successful deployment and development of RE projects in Uganda. The development of RE calls for skills in different fields that may include physics, materials science, chemical, mechanical, and electrical engineering, business management and social science [134]. Nonetheless, the different groups need precise training, since the set of skills may vary in detail for the different technologies. It is also essential that RE technology users understand the availability and explicit operational features of RE sources.

In particular, this is highly significant in the rural areas of least-developed countries such as Uganda. Technical support for diffuse RETs, such as the solar PV systems in rural communities, requires a large workforce that has a basic technical skill rather than a few experts with high technical skills. Training such artisans and ensuring that they have ready access to spare parts requires the establishment of new infrastructure that can provide a quality training platform for technical and engineering personnel. Generally, in most of the least-developed countries, the lack of such an auxiliary industry usually results in higher cost of RE projects and further barriers to deployment [131]. Presently, in Uganda, there are limited trained personnel and training facilities for the installation, operation, and maintenance of RETs which make it very difficult for the country to achieve a sustainable RE market [135].

\subsubsection{Grid Unreliability}

Another key issue holding back the development of RETs in Uganda is the absence of subsidiary infrastructure. At present, there are few transmission and distribution lines in rural and remote areas where load demand is low [136,137]. The reason has been that the extension of high-voltage transmission lines to these areas is not cost effective and inefficient [136,137]. The unsteady nature of the electricity grid in most parts of Uganda is also seen as a big challenge during power off-take (shedding of power) from the main RE source, i.e., hydropower. As a result, off-grid/standalone RE technology projects will better serve as suitable solutions to the development of rural and remote electrification.

A further infrastructure challenge is that, unlike most RETs which are generally decentralized in nature, the current electrical power system used in Uganda has been designed in a way to support the needs of centralized systems [35]. This implies that there is a need to adapt decentralized energy systems that can efficiently and effectively support RETs. 


\subsubsection{Ineffectual Quality Control of Products}

The lack of national technical standards and operational quality control units in Uganda can be recognized as a key dispute to the acceptance of RE in households. This can be traceable to a lack of appropriate training and personnel as previously discussed [131,135]. Furthermore, a number of RETs are described by the absence of minimum standards in terms of performance, durability, reliability [73], etc., thus upsetting the opportunities for large-scale commercialization [135]. Currently, there are no standards and regulating requirements for RE products; products are also without manufacturers' certificates of analysis [42,43]. This has led to the inflow of a huge amount of substandard/poor quality RE equipment such as solar components and systems into the country. For instance, most of the solar products are basically imported from China through various neighboring borders into the marketplace at cheaper prices $[138,139]$. However, despite the fact that the sub-standard components/products are cheaper, they become more expensive over time, as the components will often be replaced and thus affect the performance and efficiency of the entire solar PV system.

\subsubsection{Institutional Barriers}

The institutional structure of the energy sector in most developing/least-developed countries such as Uganda is still under government monopoly, with the responsibility for energy generation and distribution allocated among a number of government departments [132]. However, insufficient coordination due to an array of government bodies with energy authority and the limitation of institutional capacity constituent critical institutional hindrances to the production of RETs in Uganda [132]. This in turn creates an unsteady macro-economic environment which increases risks and dampens investments. This barrier exists not only because Uganda is still a low-income/less-developed country, but also as a result of the inadequate attention of the government to R\&D and the government's failure to facilitate science activities while improving human resources. In addition, there are no regional or national research centers with the required basic research facilities and infrastructures for RETs [134].

Furthermore, the GoU needs to realize that, at the institutional level, the centralized energy model is becoming increasingly redundant in developed nations [35]. Instead of expanding its centralized power systems, Uganda needs to focus more on the development of a decentralized energy structure that would better match its current capital resources and management ability. This will help position the country to adapt to future energy technologies and systems.

\section{Efficient Measures and Policies Required in Overcoming Barriers to Renewable Energy Development in Uganda}

To prevail over the aforementioned barriers and hasten the development of RE applications in Uganda, there is a need for the GoU to introduce favorable policies at different levels of the government. These policy frameworks are basic premises needed by the GoU to apply, extend and assess its policies and succeeding actions that may include legislation, enforcement, decision-making etc. This will effectively tackle major RE concerns that are captured in the policy framework and others which are not. The following efficient measures and policies are thereby suggested, in order to accelerate RE development in Uganda.

\subsection{Alleviation of Political and Regulatory Investment Risk}

Investment risk can be traceable to several factors, but the most prominent one is political and regulatory risk $[140,141]$. This displays a major restriction on investment decisions and it is regarded as the utmost deterrent for any investments into emerging markets, such as RE energy. It is as a result of this risk that some investors, even when looking for investment opportunities urgently, will simply not put into consideration an RE infrastructure asset in an emerging and developing nation. 
Certainly, a refined system of regulation is beneficial to the society, and RE infrastructure investors mostly do not have any problem with them. Instead, their concern is always about the unexpected changes in the laws and regulation. For instance, how the political and regulatory risk that takes place relates predominantly to RE infrastructure investments. As a result of this discrepancy between political and RE infrastructure sequences, RE infrastructure investors are reasonably guarded. They desire to be quite sure not only that the existing government meets its obligations but also that the decision of a future legislature or RE management will not impinge on their investment in a severe manner. This implies that the RE sector of Uganda will clearly need thoughtful regulation that can avert the abuse of pricing power.

Furthermore, by taking into consideration the significance of RE development in Uganda, the government should possibly establish a particular body that will be responsible for the management of all the activities related to RE projects across the country. This will be of great assistance in streamlining the urgent but important needs in the RE sector as it is in some developed countries. As such, enforcing reputable laws are also necessary steps required to decrease the basic hindrances of the political and regulatory risk in Uganda. The enhancement of vital reform processes in social, political, economic planning can help manage corrupt practices while establishing transparency ethics in the public administration.

\subsection{Energy Subsidy Transfer and Cost Reduction Measures}

It would be a courageous and crucial step for the GoU to consider transferring subsidies from fossil fuels to RETs. A step towards this direction will bridge the competitive gap between RETs and fossil fuels [142,143]. For instance, the subsidies on kerosene (used for flammable kerosene lantern) can be transferred to solar lanterns as an alternative. Another challenge is that there is inadequate funding for RE projects in Uganda, particularly for small-scale projects. Part of this complication comes from a lack of awareness as regards RETs, and ambiguity regarding the consistency of energy resource assessments. Moreover, the capital cost of RETs is somewhat high and this discourages funding agencies.

Presently, the GoU made available economic incentives that include tariff waivers, subsidies etc. to promote investments in energy through fossil energy sources. One of the main reasons for subsidizing fossil fuels is to protect domestic prices from the unpredictable global market [124]. Also, subsidies propel the prices of fossil fuel energy down, while positioning the already capital-demanding RETs at more disadvantages. Most of these incentives are not open to RE technology projects, and these are factors that play major roles in the obstruction of RE development in Uganda. However, changing these subsidies for fossil fuels to support the necessary incentive methods for RE development will definitely hasten the development of these resources in Uganda, particularly solar energy.

In spite of the continuous efforts from the government to subsidize electricity, the schemes have failed to meet the electricity need in the country. This may be ascribed to the avenues and approaches used by the authorities for subsidization. The country has undergone the rising burden of subsidizing electricity in the midst of a deflating shilling. Nevertheless, this kind of financial support is durable for a short period and not cost-effective as it leads to additional pollution. Thus, the establishment of incentives for households and rural communities to install small-scale RE systems in their propinquity will be a long-term solution.

\subsection{Favorable Feed-in-Tariffs Policies}

Although Uganda is one of the pioneers of FiTs in Africa, this policy needs to be properly managed with the intentions of attracting possible investors and simultaneously their activities should be closely monitored. However, to achieve a smooth process of renewable energy feed-in-tariffs (REFITs), the government would need to appoint skilled personnel that will be responsible for the handling of the process. This is because favorable policies are primary requirements for the long-term sustainability of RE development. Thus, making sure that laws are established and obligatory is very 
important as prospective investors will need realistic assurance that the legislative necessities put in place for RE activities will remain steady, explicit and enforced, thereby promoting future stability of investment.

Furthermore, for worthwhile investment in RE power generation, the electricity tariff must be market-reflective, irrespective of the accessibility of fossil fuel energy sources. This will persuade potential stakeholders to invest in RE applications. On the other hand, an increase in the tariff regimen could be counter-productive, bearing in mind that a larger fraction of the populace belongs to the low-income class and that costs are circulated among electricity consumers as fraction of their regular bill [144].

Nevertheless, REFITs in Uganda can also be a valuable policy means of increasing RE technology deployment, just as FiTs have been lucratively engaged in several developed and developing countries. The implementation of REFITs will be an important policy mechanism that can be used to boost the deployment of RETs and improve affordability. It also assures payment to RE investors at a set price for electricity production over a period of 15 to 20 years. These tariff charges can be predetermined based on the cost of power generation of specific technologies but usually reduced over time [145].

\subsection{Consistent Information and Technology Awareness Creation}

The implementation of large-scale RE applications can only be embarked upon successfully if there is an improved understanding and support of the public. Hence, an increased awareness of the prospect and advantages associated with the development of RETs, and the fundamental advantage for climate change alleviation is quite important to swiftly and appreciably enhance the desire and interest among the Ugandan populace.

Primarily, a centralized data-based information center that is both comprehensive and accessible to the public needs to be established. This center will be expected to keep records of the various field experience acquired during the installation, operation and maintenance of RE technology systems and make available information that is related to RE incentives, RETs, RE policies and the utilization of RETs systems for small-scale investors. Such information can act as an important tool for learning and thereby allowing RE contractors to expand and adapt RETs for particular environmental conditions. This center will not only serve a means of assessing resources, but also as a monitoring and evaluation means. Thus, with proper management of the center, there will be increase in general awareness, reception and interest in RETs. It is therefore clear that an increased access to RE technology-related information and technology is crucial to the successful development of RE projects in Uganda.

\subsection{Establishment and Enforcement of Quality Standards for Renewable Energy Technologies Equipment}

A lot of impediments as a result of poor-quality of RETs such as solar PV systems have deteriorated some solar energy projects in this country. As a result, standardization of RE manufacturing procedure is necessary to strengthen small-scale RE industries. For instance, the Uganda National Bureau of Standards (UNBS) and other government agencies must set up and strictly enforce appropriate manufacturing standards and specifications. This can be achieved by introducing policy instruments and incentives that can encourage local assembling of RE devices.

Likewise, for the purpose of sustainability, the government needs to also make efforts to introduce domestic manufacturing industry for RETs, thus reducing the reliance on the imported products. This is particularly applicable to solar energy technology. With the implementation of these standard production procedures, the quality and quantity of RE output will yield increase. This will be a step in the right direction that would entirely empower the RE industries.

\section{Conclusions}

Uganda has been struggling to unravel its energy deficiency problems for years now. With the nation faced with an unprecedented energy crisis, the urge to secure efficient long-term solutions to its energy needs is getting stronger by the day. RE resources such as biomass, hydro, solar, wind etc. are 
abundant in Uganda and they exhibit significant practical potential to meet the nation's energy needs. Nevertheless, the development of RE projects is hampered by impediments that include informational, economic, institutional, social, and technical barriers. The March 2007-approved RE policy reinforced the commitment of the GoU to take important steps toward uplifting RE technology deployment. However, quite a lot of the policy challenges are yet to be addressed. The key to consolidating the existence of RETs in Uganda does not lie just in the individual solutions to the policy challenges; rather, an all-inclusive technique must be engaged. In this paper, we have presented the review of the potential of RE utilization and development in the country. The current status of the RETs have been reviewed and the present RE related policy instruments and measures have also been analyzed. The barriers and challenges associated with the development of RE applications have been discussed and significant policies required to overcome the identified barriers and challenges are suggested for the future growth of RE technology in Uganda.

In our view, we suggest that the Ugandan government should take bold steps towards reforming and implementing its RE policy with the intention of increasing energy security and moving the country towards a sustainable energy future. Above all, these policies should be centered on linking the competitive gap between RETs and fossil fuels via measures such as effective feed-in tariffs, energy subsidy transfers, and accounting for negative and positive excessive attention to externalities. Obviously, increasing the keenness of RETs only is not enough; disputes such as poor infrastructure, absence of assess to appropriate funding and technology also have to be dealt with. Moreover, the most significant challenge is primarily situated in the need to first stimulate growth in RE. By tackling the main challenge faced by RETs, market diffusion will obviously develop and the necessary provision needed to address further challenges facing RETs will follow.

Accordingly, the direction towards a sustainable energy future in Uganda is in no way simple, yet at the same time a solution definitely exists. Regardless of the numbers of approaches that may have been presented in this study to foster the growth of RE in Uganda, these solutions will certainly require significant efforts and dedication on the part of the Ugandan government. Uganda should therefore consider the long-term benefits (economic, environmental, and social) of RE power generation for its citizens. Uganda's investment on sustainable energy technologies today will thus lead to a secure energy future for tomorrow.

Author Contributions: All authors contributed in writing, proofreading and providing suggestions for improving the article.

Conflicts of Interest: The authors declare no conflict of interest.

\section{References}

1. Review Report on Uganda's Readiness for the Implementation of Agenda 2030. Available online: https:// sustainabledevelopment.un.org/content/documents/10689Uganda\%20Review\%20Report_CDs1.pdf (accessed on 12 March 2016).

2. Istituto Afari Internazionali (IAI); European Centre for Development Policy Management (ECDPM). A New EU Strategic Approach to Global Development, Resilience and Sustainability; IAI Working Papers 16 (14); IAI: Rome, Italy, May 2016; ISSN 2280-4331. ISBN 978-88-98650-94-1.

3. UN Africa-Sustainable Development Knowledge Platform "Implementation of the United Nations Convention to Combat Desertification in Those Countries Experiencing Serious Drought and/or Desertification, Particularly in Africa: Report of the Second Committee" (A/70/472/Add.5), 14 December 2015. Available online: http: / /www.un.org/ga/search/view_doc.asp?symbol=A/70/472/Add.5\&Lang=E (accessed on 12 March 2016).

4. UN General Assembly, Transforming Our World: The 2030 Agenda for Sustainable Development (A/RES/70/1). 25 September 2015. Available online: http:/ / undocs.org/A/RES/70/1 (accessed on 12 June 2017).

5. Emodi, N.V.; Boo, K. Sustainable Energy Development in Nigeria: Overcoming Energy Poverty. Int. J. Energy Econ. Policy 2015, 5, 580-597.

6. Ebohon, O.J. Energy, economic growth and causality in developing countries: A case study of Tanzania and Nigeria. Energy Policy 1996, 24, 447-453. [CrossRef] 
7. Omer, A.M. Energy, environment and sustainable development. Renew. Sustain. Energy 2008, 12, $2265-2300$. [CrossRef]

8. Dincer, I. Renewable energy and sustainable development: A crucial review. Renew. Sustain. Energy 2000, 4, 157-175. [CrossRef]

9. Kanagawa, M.; Nakata, T. Analysis of the energy access improvement and its socio-economic impacts in rural areas of developing countries. Ecol. Econ. 2007, 62, 319-329. [CrossRef]

10. Kanagawa, M.; Nakata, T. Assessment of access to electricity and the socio-economic impacts in rural areas of developing countries. Energy Policy 2008, 36, 2016-2029. [CrossRef]

11. Jiang, Z.; Lin, B. China's energy demand and its characteristics in the industrialization and urbanization process. Energy Policy 2012, 49, 608-615. [CrossRef]

12. Jones, D.W. How urbanization affects energy-use in developing countries. Energy Policy 1991, 19, 621-630. [CrossRef]

13. Jones, D.W. Urbanization and energy use in economic development. Energy J. 1991, 10, 29-44. [CrossRef]

14. Rasul, G. Managing the food, water, and energy nexus for achieving the Sustainable Development Goals in South Asia. Environ. Dev. 2016, 18, 14-25. [CrossRef]

15. Colombo, E.; Masera, D.; Bologna, S. Renewable energies to promote local development. In Renewable Energy for Unleashing Sustainable Development; Springer: Cham, Switzerland, 2013; pp. 3-25.

16. Akenji, L.; Bengtsson, M. Making sustainable consumption and production the core of sustainable development goals. Sustainability 2014, 6, 513-529. [CrossRef]

17. Shaaban, M.; Petinrin, J.O. Renewable energy potentials in Nigeria: Meeting rural energy needs. Renew. Sustain. Energy Rev. 2014, 29, 72-84. [CrossRef]

18. Subedi, M.; Matthews, R.; Pogson, M.; Abegaz, A.; Balana, B.; Oyesiku-blakemore, J.; Smith, J. Can biogas digesters help to reduce deforestation in Africa? Biomass Bioenergy 2014, 70, 1-12. [CrossRef]

19. Deichmann, U.; Meisner, C.; Murray, S.; Wheeler, D. The economics of renewable energy expansion in rural Sub-Saharan Africa. Energy Policy 2011, 39, 215-227. [CrossRef]

20. Mohammed, Y.S.; Mustafa, M.W.; Bashir, N. Status of renewable energy consumption and developmental challenges in Sub-Sahara Africa. Renew. Sustain. Energy Rev. 2013, 27, 453-463. [CrossRef]

21. Mohammed, Y.S.; Mokhtar, A.S.; Bashir, N.; Saidur, R. An overview of agricultural biomass for decentralized rural energy in Ghana. Renew. Sustain. Energy Rev. 2013, 20, 15-25. [CrossRef]

22. Nfah, E.M.; Ngundam, J.M.; Vandenbergh, M.; Schmid, J. Simulation of off-grid generation options for remote villages in Cameroon. Renew. Energy 2008, 33, 1064-1072. [CrossRef]

23. Suberu, Y.; Bashir, N.; Wazir, M. Overuse of wood-based bioenergy in selected sub-Saharan Africa countries: Review of unconstructive challenges and suggestions. J. Clean. Prod. 2015, 96, 501-519.

24. Kaunda, CS. Energy situation, potential and application status of small-scale hydropower systems in Malawi. Renew. Sustain. Energy Rev. 2013, 26, 1-19. [CrossRef]

25. Nzila, C.; Dewulf, J.; Spanjers, H.; Kiriamiti, H.; Van Langenhove, H. Biowaste energy potential in Kenya. Renew. Energy 2010, 35, 2698-2704. [CrossRef]

26. Kihwele, S.; Hur, K.; Kyaruzi, A. Visions, scenarios and action plans towards next generation Tanzania power system. Energies 2012, 5, 3908-3927. [CrossRef]

27. Okello, C.; Pindozzi, S.; Faugno, S.; Boccia, L. Bioenergy potential of agricultural and forest residues in Uganda. Biomass Bioenergy 2013, 56, 515-525. [CrossRef]

28. Kousksou, T.; Allouhi, A.; Belattar, M.; Jamil, A.; El Rhafiki, T.; Arid, A.; Zeraouli, Y. Renewable energy potential and national policy directions for sustainable development in Morocco. Renew. Sustain. Energy Rev. 2015, 47, 46-57. [CrossRef]

29. Hensley, M.; Gu, S.; Ben, E. A comprehensive review of biomass resources and biofuels potential in Ghana. Renew. Sustain. Energy Rev. 2011, 15, 404-415.

30. Osei, W.Y.A.W. Rural energy technology: Issues and options for sustainable development in Ghana. Geoforum 1996, 27, 63-74. [CrossRef]

31. Kiplagat, J.K.; Wang, R.Z.; Li, T.X. Renewable energy in Kenya: Resource potential and status of exploitation. Renew. Sustain. Energy Rev. 2011, 15, 2960-2973. [CrossRef]

32. Tong, T.M.; Asare, J.; Rwenyagila, E.R.; Anye, V.; Oyewole, O.K; Fashina, A.A.; Soboyejo, W.O. A Study of Factors that Influence the Adoption of Solar Powered Lanterns in a Rural Village in Kenya. Perspect. Glob. Dev. Technol. 2015, 14, 448-491. [CrossRef] 
33. Okello, C.; Pindozzi, S.; Faugno, S.; Boccia, L. Development of bioenergy technologies in Uganda: A review of progress. Renew. Sustain. Energy Rev. 2013, 18, 55-63. [CrossRef]

34. Nsamba, H.K.; Hale, S.E.; Cornelissen, G.; Bachmann, R.T. Sustainable technologies for small-scale biochar production-A review. J. Sustain. Bioenergy Syst. 2015, 5, 10-31. [CrossRef]

35. Twaha, S.; Ramli, M.A.; Murphy, P.M.; Mukhtiar, M.U.; Nsamba, H.K. Renewable based distributed generation in Uganda: Resource potential and status of exploitation. Renew. Sustain. Energy Rev. 2016, 57, 786-798. [CrossRef]

36. Akella, A.K.; Saini, R.P.; Sharma, M.P. Social, economical and environmental impacts of renewable energy systems. Renew. Energy 2009, 34, 390-396. [CrossRef]

37. Chien, T.; Hu, J.L. Renewable energy: An efficient mechanism to improve GDP. Energy Policy 2008, 36, 3045-3052. [CrossRef]

38. Sadorsky, P. Renewable energy consumption and income in emerging economies. Energy Policy 2009, 37, 4021-4028. [CrossRef]

39. BP, P.L.C. BP: Statistical Review of World Energy Workbook (xlsx); BP P.L.C.: London, UK, June, 2017. Available online: https://www.bp.com/content/dam/bp/en/corporate/pdf/energy-economics/statistical-review2017/bp-statistical-review-of-world-energy-2017-full-report.pdf (accessed on 12 March 2016).

40. Energy Information Administration. International Energy Statistics; Retrieved 5 June 2013; Energy Information Administration: Paris, France, 2016.

41. Karekezi, S. Disseminating renewable energy technologies in sub-Saharan Africa. Annu. Rev. Energy Environ. 1994, 19, 387-421. [CrossRef]

42. Karekezi, S. Renewables in Africa-Meeting the energy needs of the poor. Energy Policy 2002, 30, 1059-1069. [CrossRef]

43. Norton Rose Fulbright (NRFC). Investing in the Electricity Sector in Uganda; Norton Rose Fulbright (NRFC): Hong Kong, China, February 2015.

44. Ministry of Energy and Mineral Development. Strategic Investment Plan 2014/15-2018/19; Ministry of Energy and Mineral Development: Kampala, Uganda, 2014.

45. World Bank. Sustainable Energy for All (SE4ALL) Database; from the SE4ALL Global Tracking Framework Led Jointly by the World Bank, International Energy Agency and the Energy Sector Management Assistance Program; World Bank: Washington, DC, USA, 2017.

46. PWC. Uganda Budget. August 5, 2013 Version. Available online: http://www.pwc.com/en_UG/ug/assets/ pdf/uganda-budget-2013.pdf (accessed on 26 February 2017).

47. Teke, A.; Timur, O. Assessing the energy efficiency improvement potentials of HVAC systems considering economic and environmental aspects at the hospitals. Renew. Sustain. Energy Rev. 2014, 33, 224-235. [CrossRef]

48. Drazu, C.; Olweny, M.; Kazoora, G. Household energy use in Uganda: existing sources, consumption, and future challenges. In Living and Learning: Research for a Better Built Environment: 49th International Conference of the Architectural Science Association 2015; Crawford, R.H., Stephan, A., Eds.; The Architectural Science Association of The University of Melbourne: Victoria, Australia, 2015; pp. 352-361.

49. Luis, D.; Oliveira, D.; Brandao, L.E.; Igrejas, R.; Lima, L. Switching outputs in a bioenergy cogeneration project: A real options approach. Renew. Sustain. Energy Rev. 2014, 36, 74-82.

50. Muloni, I. Renewable Energy Investment Guide May 2012 Version; Electricity Regulatory Authority: Kampala Uganda, 2012.

51. GWEC: Global Wind Statistics Report Annual Market Update 2016 Version. Available online: http:/ / www. gwec.net/wp-content/uploads/vip/GWEC_PRstats2016_EN_WEB.pdf (accessed on 26 February 2017).

52. Panwar, N.L.; Kaushik, S.C.; Kothari, S. Role of renewable energy sources in environmental protection: A review. Renew. Sustain. Energy Rev. 2011, 15, 1513-1524. [CrossRef]

53. Association WWE. World Wind Energy Report 2008; WWEA: Bonn, Germany, 2009. Available online: www. wwindea.org/home/images/ / worldwindenergyreport2008 (accessed on 26 February 2017).

54. Buchholz, T.; Da Silva, I. Potential of distributed wood-based biopower systems serving basic electricity needs in rural Uganda. Energy Sustain. Dev. 2010, 14, 56-61. [CrossRef]

55. Center for Energy Efficiency and Renewable Energy. Wind Power: Capacity Factor, Intermittency, and What Happens When the Wind Doesn't Blow? 2010. Available online: http:/ /www.ceere.org/rerl/about_wind/ RERL_Fact_Sheet_2a_Capacity_Factor.pdf (accessed on 26 February 2017). 
56. Bhutto, A.W.; Bazmi, A.A.; Zahedi, G. Greener energy: Issues and challenges for Pakistan-Wind power prospective. Renew. Sustain. Energy Rev. 2013, 20, 519-538. [CrossRef]

57. Elistratov, V.V. The development of the wind power industry in Russia. Wind Power World Int. Rev. Dev. 2013, 3,443 .

58. Dabiri, J.O.; Greer, J.R.; Koseff, J.R.; Moin, P.; Peng, J. A new approach to wind energy: Opportunities and challenges. In Proceedings of the AIP Conference Proceedings, Berkeley, CA, USA, 8-9 March 2014; Volume 1652, pp. 51-57.

59. Sathaye, J.; Lucon, O.; Rahman, A.; Christensen, J.; Denton, F.; Fujino, J.; Heath, G.; Mirza, M.; Rudnick, H.; Schlaepfer, A.; et al. Renewable Energy in the Context of Sustainable Development; Cambridge University Press: Cambridge, UK, 2011.

60. Twidell, J.; Weir, T. Renewable Energy Resources; Routledge: Abingdon, UK, 2015.

61. Karekezi, S.; Kithyoma, W.; Initiative, E. Renewable Energy Development. In Proceedings of the Workshop on African Energy Experts on Operationalizing the NEPAD Energy Initiative, Dakar, Senegal, 2-4 June 2003; pp. 2-4.

62. Karekezi, S.; Kithyoma, W. Renewable energy strategies for rural Africa: Is a PV-led renewable energy strategy the right approach for providing modern energy to the rural poor of sub-Saharan Africa? Energy Policy 2002, 30, 1071-1086. [CrossRef]

63. Brew-Hammond, A. Energy access in Africa: Challenges ahead. Energy Policy 2010, 38, 2291-2301. [CrossRef]

64. Rabah, K.V. Integrated solar energy systems for rural electrification in Kenya. Renew. Energy 2005, 30, $23-42$. [CrossRef]

65. Alazraque-Cherni, J. Renewable energy for rural sustainability in developing countries. Bull. Sci. Technol. Soc. 2008, 28, 105-114. [CrossRef]

66. Ahuja, D.; Tatsutani, M. Sustainable energy for developing countries. 2009. Available online: http://journals. openedition.org/sapiens/823 (accessed on 6 May 2018).

67. Bilgili, M.; Ozbek, A.; Sahin, B.; Kahraman, A. An overview of renewable electric power capacity and progress in new technologies in the world. Renew. Sustain. Energy Rev. 2015, 49, 323-334. [CrossRef]

68. Kammen, D.M. Solar Cooking for Developing Nations; Harvard University: Cambridge, MA, USA, 1991.

69. Kammen, D.M. The Kenya Solar Box: Appropriate Dissemination in Africa. In Africa Technology Forum, February/March 1992; African Technology Forum: Cambridge, UK, 1992; Volume 3.

70. Baanabe, J. Energy supply in Uganda. In Proceedings of the National Workshop on Promoting Sustainable Transport Solutions for East Africa, Nairobi, Kenya, 7-8 August 2012.

71. Moner-Girona, M.; Ghanadan, R.; Jacobson, A.; Kammen, D.M. Decreasing PV costs in Africa: Opportunities for rural electrification using solar PV in sub-Saharan Africa. Refocus 2006, 7, 40-45. [CrossRef]

72. Kamese, G. Renewable Energy Technologies in Uganda: The Potential for Geothermal Energy; A Country Study Report under the AFREPREN/HBF Study; Heinrich Boell Foundation: Berlin, Germany, 2004.

73. Fashina, A.A.; Azeko, S.T.; Asare, J.; Ani, C.J.; Anye, V.C.; Rwenyagila, E.R.; Dandogbesi, B.; Oladele, O.; Dyeris, M. A Study on the Reliability and Performance of Solar Powered Street Lighting Systems. Int. J. Sci. World 2017, 7, 110-118. [CrossRef]

74. Fashina, A.A.; Adama, K.K.; Oyewole, O.K.; Anye, V.C.; Asare, J.; Zebaze Kana, M.G.; Soboyejo, W.O. Surface Texture and Optical Properties of Crystalline Silicon Substrates. J. Renew. Sustain. Energy 2015, 7, 063119-1-063119-11. [CrossRef]

75. Hansen, U.E.; Pedersen, M.B.; Nygaard, I. Review of Solar PV Market Development in East Africa; UNEP Risø Centre, Technical University of Denmark: Kongens Lyngby, Denmark, 2014.

76. Mawejje, J.; Munyambonera, E.; Bategeka, L. Uganda's Electricity Sector Reforms and Institutional Restructuring; Economic Policy Research Centre: Kampala, Uganda, 2012.

77. Pedersen, M.B. Deconstructing the concept of renewable energy-based mini-grids for rural electrification in East Africa. Wiley Interdiscip. Reviews Energy Environ. 2016, 5, 570-587. [CrossRef]

78. Renewable Energy \& Energy Efficiency Partnership. Renewable Energy Potential in Uganda. Available online: http:/ / www.afribiz.info (accessed on 6 September 2017).

79. InfraCo Africa. Kalangala Infrastructure Services. Available online: http://www.infracoafrica.com/projects. asp (accessed on 6 September 2017).

80. Folkecenter. Solar Energy in Uganda. Available online: http://www.folkecenter.net (accessed on 6 September 2017). 
81. Bahati, G. Geothermal Energy in Uganda, Country Update. In Proceedings of the International Geothermal Conference, Reykjavik Iceland, 14-17 September 2003.

82. Bowen, R. Geothermal Resources; Springer Science \& Business Media: Berlin, Germany, 2012.

83. Glassley, W.E. Geothermal Energy: Renewable Energy and the Environment; CRC Press: Boca Raton, FL, USA, 2014.

84. Energy Sector GIS Working Group Gets Award for Best Map. Available online: http:/ / www.energyprogramme. or.ug/giz-uganda-gets-award-for-best-gismap/2012 (accessed on 6 September 2017).

85. Uganda Bureau of Statistics. Statistical Abstract; Uganda Bureau of Statistics: Entebbe, Uganda, 2013.

86. Laurea University of Applied Sciences. About Uganda. Available online: https://www.laurea.fi/dokumentit/ Documents/Uganda;CountryReport.pdf (accessed on 6 September 2017).

87. Bartle, A. Hydropower potential and development activities. Energy Policy 2002, 30, 1231-1239. [CrossRef]

88. Mudoko, S.N. Uganda's Policy on Energy and Power. Presented at ICA Training on Energy Policy, Tokyo, Japan, 2 June 2013.

89. UMEME. About UMEME. Available online: http://www.umeme.co.ug/index.php?page \protect\$relax protect $\{$ begingroup1 \endgroup \@@over4\}\$MTUw (accessed on 6 September 2017).

90. McKendry, P. Energy production from biomass (part 1): Overview of biomass. Bioresour. Technol. 2002, 83, 37-46. [CrossRef]

91. Rittmann, B.E. Opportunities for renewable bioenergy using microorganisms. Biotechnol. Bioeng. 2008, 100, 203-212. [CrossRef] [PubMed]

92. Karaj, S.; Rehl, T.; Leis, H.; Müller, J. Analysis of biomass residues potential for electrical energy generation in Albania. Renew. Sustain. Energy Rev. 2010, 14, 493-499. [CrossRef]

93. Demirbaş, A. Biomass resource facilities and biomass conversion processing for fuels and chemicals. Energy Convers. Manag. 2001, 42, 1357-1378. [CrossRef]

94. Openshaw, K. Biomass energy: Employment generation and its contribution to poverty alleviation. Biomass Bioenergy 2010, 34, 365-378. [CrossRef]

95. Bingh, LP. Opportunities for Utilizing Waste Biomass for Energy in Uganda. Master's Thesis, Institutt for Energi-og Prosessteknikk, Trondheim, Norway, 2004.

96. Khundi, F.; Jagger, P.; Shively, G.; Sserunkuuma, D. Income, poverty and charcoal production in Uganda. For. Policy Econ. 2011, 13, 199-205. [CrossRef]

97. Kshirsagar, M.P.; Kalamkar, V.R. A comprehensive review on biomass cookstoves and a systematic approach for modern cookstove design. Renew. Sustain. Energy Rev. 2014, 30, 580-603. [CrossRef]

98. Habermehl, H. Economic Evaluation of the Improved Household Cooking Stove Dissemination Programme in Uganda; GTZ: Eschborn, Germany, 2007.

99. Adkins, E.; Tyler, E.; Wang, J.; Siriri, D.; Modi, V. Field testing and survey evaluation of household biomass cookstoves in rural sub-Saharan Africa. Energy Sustain. Dev. 2010, 14, 172-185. [CrossRef]

100. Kees, M.; Feldmann, L. The role of donor organisations in promoting energy efficient cook stoves. Energy Policy 2011, 39, 7595-7599. [CrossRef]

101. Hankey, S.; Sullivan, K.; Kinnick, A.; Koskey, A.; Grande, K.; Davidson, J.H.; Marshall, J.D. Using objective measures of stove use and indoor air quality to evaluate a cookstove intervention in rural Uganda. Energy Sustain. Dev. 2015, 25, 67-74. [CrossRef]

102. Roopnarain, A.; Adeleke, R. Current status, hurdles and future prospects of biogas digestion technology in Africa. Renew. Sustain. Energy Rev. 2017, 67, 1162-1179. [CrossRef]

103. Castellanos, J.G.; Walker, M.; Poggio, D.; Pourkashanian, M.; Nimmo, W. Modelling an off-grid integrated renewable energy system for rural electrification in India using photovoltaics and anaerobic digestion. Renew. Energy 2015, 74, 390-398. [CrossRef]

104. Karekezi, S.; Kithyoma, W.; Kamoche, M. Evaluating biomass energy cogeneration opportunities and barriers in Africa: The case of bagasse cogeneration in the sugar industry. In Bio-Carbon Opportunities in Eastern $\mathcal{E}$ Southern Africa; UNDP: New York, NY, USA, 2009; p. 179.

105. Siddiqui, M.U.; Said, S.A.M. A review of solar powered absorption systems. Renew. Sustain. Energy Rev. 2015, 42, 93-115. [CrossRef]

106. Eksi, G.; Karaosmanoglu, F. Combined bioheat and biopower: A technology review and an assessment for Turkey. Renew. Sustain. Energy Rev. 2017, 73, 1313-1332. [CrossRef]

107. Adeyemi, K.O.; Asere, A.A. A review of the energy situation in Uganda. Int. J. Sci. Res. Publ. 2014, 4, 1-4. 
108. Othieno, H.; Awange, J. Global Energy Perspective. In Energy Resources in Africa; Springer: Cham, Switzerland, 2016; pp. 1-32.

109. United Nations, Department of Economic and Social Affairs, Population Division (2015). World Population Prospects: The 2015 Revision, Key Findings and Advance Tables. Working Paper No. ESA/P/WP.241.

110. LeTreut, H. Greenhouse gases, aerosols and reducing future climate uncertainties. Surv. Geophys. 2012, 33, 723-731. [CrossRef]

111. Moomaw, W.; Yamba, F.; Kamimoto, M.; Maurice, L.; Nyboer, J.; Urama, K.; Weir, T. Introduction. In IPCC Special Report on Renewable Energy Sources and Climate Change Mitigation; Edenhofer, O., Pichs-Madruga, R., Sokona, Y., Seyboth, K., Matschoss, P., Kadner, S., Zwickel, T., Eickemeier, P., Hansen, G., Schlomer, S., et al., Eds.; Cambridge University Press: Cambridge, UK; New York, NY, USA, 2011; pp. 161-209.

112. Suberu, M.Y.; Mustafa, M.W.; Bashir, N.; Muhamad, N.A.; Mokhtar, A.S. Power sector renewable energy integration for expanding access to electricity in sub-Saharan Africa. Renew. Sustain. Energy Rev. 2017, 25, 630-642. [CrossRef]

113. Wodon, Q.; Ninan, E.; Mulindwa, I.; Rakotomalala, M.; Tsimpo, C. Uganda Note 2016.

114. Kapika, J.; Eberhard, A. Power-Sector Reform and Regulation in Africa: Lessons from Kenya, Tanzania, Uganda, Zambia, Namibia and Ghana; HSRC Press: Cape Town, South Africa, 2013.

115. Mawejje, J.; Munyambonera, E.; Bategeka, L. Powering ahead: The reform of the electricity sector in Uganda. Energy Environ. Res. 2013, 3, 126. [CrossRef]

116. Eberhard, A. Powering Africa: Facing the Financing and Reform Challenges. Revue d'Économie du Développement 2015, 23, 39-48. [CrossRef]

117. Eberhard, A.; Gratwick, K.; Morella, E.; Antmann, P. Independent Power Projects in Sub-Saharan Africa: Investment trends and policy lessons. Energy Policy 2017, 108, 390-424. [CrossRef]

118. Van Dijk, A.L.; Beurskens, L.W.M.; Boots, M.G.; Kaal, M.B.T.; De Lange, T.J.; Van Sambeek, E.J.W.; Uyterlinde, M.A. Renewable Energy Policies and Market Developments; ECN: Petten, The Netherlands, 2003.

119. Komen, J. Africa Rising'to a Sustainable Future: Economic Prospects of Bio-Economy Development in Eastern Africa; ILRI: Nairobi, Kenya, 2016. Available online: https:/ / cgspace.cgiar.org/bitstream/handle/10568/77281/ chapter_2.pdf?sequence=1 (accessed on 7 April 2018).

120. Nilsson, A.; Johansson, I. Laying Foundation for Energy Policy Making in Uganda by Indicating the Energy flow. Available online: http://www.diva-portal.org/smash/get/diva2:840902/FULLTEXT01.pdf (accessed on 7 April 2018).

121. ADB Group. Uganda Receives Endorsement of Plan to Transform Energy through Geothermal, Solar and Wind Resources. Available online: https:/ / www.afdb.org/en/news-and-events/uganda-receives-endorsement-ofplan-to-transform-energy-through-geothermal-solar-and-wind-resources-14992/ (accessed on 16 July 2017).

122. Kaunda, C.S.; Kimambo, C.Z.; Nielsen, T.K. Potential of small-scale hydropower for electricity generation in Sub-Saharan Africa. ISRN Renew. Energy 2012, 2012, 132606. [CrossRef]

123. Patterson, M.G. What is energy efficiency? Concepts, indicators and methodological issues. Energy Policy 1996, 24, 377-390. [CrossRef]

124. Halkos, G.E.; Tzeremes, N.G. Renewable energy consumption and economic efficiency: Evidence from European countries. J. Renew. Sustain. Energy 2013, 5, 041803. [CrossRef]

125. Bin, S.; Dowlatabadi, H. Consumer lifestyle approach to US energy use and the related $\mathrm{CO}_{2}$ emissions. Energy Policy 2005, 33, 197-208. [CrossRef]

126. Ramli, M.A.; Twaha, S. Analysis of renewable energy feed-in tariffs in selected regions of the globe: Lessons for Saudi Arabia. Renew. Sustain. Energy Rev. 2015, 45, 649-661. [CrossRef]

127. Mustapa, S.I.; Peng, L.Y.; Hashim, A.H. Issues and challenges of renewable energy development: A Malaysian experience. In Proceedings of the 2010 International Conference on Energy and Sustainable Development: Issues and Strategies (ESD), Chiang Mai, Thailand, 2-4 June 2010; IEEE: Piscataway, NJ, USA, 2010; pp. 1-6.

128. Peidong, Z.; Yanli, Y.; Yonghong, Z.; Lisheng, W.; Xinrong, L. Opportunities and challenges for renewable energy policy in China. Renew. Sustain. Energy Rev. 2009, 13, 439-449. [CrossRef]

129. Martinot, E.; Chaurey, A.; Lew, D.; Moreira, J.R.; Wamukonya, N. Renewable energy markets in developing countries. Annu. Rev. Energy Environ. 2002, 27, 309-348. [CrossRef]

130. Verbruggen, A.; Fischedick, M.; Moomaw, W.; Weir, T.; Nadaï, A.; Nilsson, L.J.; Nyboer, J.; Sathaye, J. Renewable energy costs, potentials, barriers: Conceptual issues. Energy Policy 2010, 38, 850-861. [CrossRef] 
131. Murphy, P.M.; Twaha, S.; Murphy, I.S. Analysis of the cost of reliable electricity: A new method for analyzing grid connected solar, diesel and hybrid distributed electricity systems considering an unreliable electric grid, with examples in Uganda. Energy 2014, 66, 523-534. [CrossRef]

132. Painuly, J.P. Barriers to renewable energy penetration; a framework for analysis. Renew. Energy 2001, 24, 73-89. [CrossRef]

133. Parthasarathi, A. Priorities in science and technology for development: Need for major restructuring. Curr. Sci. 2002, 82, 1211-1219.

134. Wilkins, G. Technology Transfer for Renewable Energy; Taylor \& Francis: Abingdon, UK, 2010.

135. Raisch, V. Financial assessment of mini-grids based on renewable energies in the context of the Ugandan energy market. Energy Procedia 2016, 93, 174-182. [CrossRef]

136. Szabo, S.; Bódis, K.; Huld, T.; Moner-Girona, M. Energy solutions in rural Africa: Mapping electrification costs of distributed solar and diesel generation versus grid extension. Environ. Res. Lett. 2011, 6, 034002. [CrossRef]

137. Zomers, A. Remote access: Context, challenges, and obstacles in rural electrification. IEEE Power Energy Mag. 2014, 12, 26-34.

138. Rotberg, I.R. (Ed.) China into Africa: Trade, Aid, and Influence; Brookings Institution Press: Washington, DC, USA, 2008.

139. Cicale, N.J. The Clean Development Mechanism: Renewable Energy Infrastructure for China and an Empty Promise for Africa. Conn. J. Int. Law 2010, 26, 253.

140. Pierson, P. When effect becomes cause: Policy feedback and political change. World Polit. 1993, 45, 595-628. [CrossRef]

141. Vaughan, E.J.; Vaughan, T. Fundamentals of Risk and Insurance; John Wiley \& Sons: Hoboken, NJ, USA, 2007.

142. COMSATS. Renewable Energy Technologies and Sustainable Development. Islamabad: Commission on Science and Technology for Sustainable Development in the South; COMSATS: Islamabad, Pakistan, 2005.

143. Economic and Industrial Publications. The Free Library, Cost and Benefit of Oil Subsidy. 2008. Available online: http:/ / www.thefreelibrary.com/Cost+and+benefit+of+oil+subsidy.-a0185951419 (accessed on 10 July 2017).

144. Mendonça, M.; Jacobs, D. Feed-in Tariffs Go Global: Policy in Practice. Renew. Energy World Int. Mag. 2009, 12, 1-6.

145. DeMartino, S.; Le Blanc, D. Estimating the Amount of a Global Feed-In Tariff; DESA Working Paper; United Nations Department of Economic and Social Affairs: New York, NY, USA, 2010. 